Florida International University FIU Digital Commons

6-12-2012

\title{
Direct and Indirect Effects of Organic Matter Sources on Denitrificaton in Florida Rivers
}

Megan Fork

Florida International University,mfork@fiu.edu

DOI: $10.25148 /$ etd.FI12080627

Follow this and additional works at: https://digitalcommons.fiu.edu/etd

\section{Recommended Citation}

Fork, Megan, "Direct and Indirect Effects of Organic Matter Sources on Denitrificaton in Florida Rivers" (2012). FIU Electronic Theses and Dissertations. 701.

https://digitalcommons.fiu.edu/etd/701 


\title{
FLORIDA INTERNATIONAL UNIVERSITY
}

Miami, Florida

\section{DIRECT AND INDIRECT EFFECTS OF ORGANIC MATTER SOURCES ON DENITRIFICATION IN FLORIDA RIVERS}

\author{
A thesis submitted in partial fulfillment of \\ the requirements for the degree of \\ MASTER OF SCIENCE \\ in \\ BIOLOGY
}

by

Megan L. Fork 
To: Dean Kenneth G. Furton

College of Arts and Sciences

This thesis, written by Megan L. Fork, and entitled Direct and Indirect Effects of Organic Matter Sources on Denitrificaton in Florida Rivers, having been approved in respect to style and intellectual content, is referred to you for judgment.

We have read this thesis and recommend that it be approved.

$\begin{array}{r}\hline \text { Joseph Boyer } \\ \hline \text { James Heffernan } \\ \hline \text { Jennifer Richards } \\ \hline \text { James Fourqurean, Major Professor }\end{array}$

Date of Defense: June 12, 2012

The thesis of Megan L. Fork is approved.

\begin{tabular}{r}
\hline $\begin{array}{c}\text { Dean Kenneth G. Furton } \\
\text { College of Arts and Sciences }\end{array}$ \\
\hline Dean Lakshmi N. Reddi \\
University Graduate School
\end{tabular}

Florida International University, 2012 


\section{ACKNOWLEDGMENTS}

I owe thanks to Catherine Bravo, Ewan Isherwood, Sabrina Jamil, Sean Koester, Nate Lemoine, Evan Rehm, Kelsey Reider, Anna Schnarnagl, Jenn Sweatman, and Dr. Jim Heffernan for help in the field. Thank you to Ewan Isherwood, Gabriel Sone, Jim Heffernan, and Sean Koester for help in the lab. I also offer thanks to Dr. Yuying Zhang and Nate Lemoine for patiently helping me apply the correct statistical analyses to my data, and to the members of the Seagrass Lab and Heffernan Lab for giving me valuable feedback on drafts of this manuscript. To our lab manager, Lawrence Lopez, thanks for helping things run smoothly and safely. I further thank the SERC Nutrient Analysis Laboratory for running my water samples, and to Dr. Bill Anderson and Dr. Todd Kana for support with the MIMS.

Permits for access to state and federal lands used as field sites were awarded to me by the Florida Department of Environmental Protection, U.S. Forest Service, Florida Forest Service. I also offer special thanks to Ginger Morgan at Ichetucknee Springs State Park for giving me logistical assistance with field work, and to Wekiva Island, King's Landing, and Canoe Outpost for providing boat ramp access and parking.

I owe a debt of gratitude to my committee members Dr. Jenny Richards and Dr. Joe Boyer for their patience, guidance, and insightful questions during my research and writing. To Dr. Jim Fourqurean, my major professor, thank you for steering me straight and making sure my thinking did not occur only within the box of freshwater ecosystems. And finally, I wish to thank Dr. Jim Heffernan, my advisor during the majority of my master's work, who patiently tolerates even the silliest of questions with grace, who 
taught me how to use creativity in science, and without whom I would have lost my way countless times. Thank you for everything.

Thank you to Sigma Xi, who awarded me a Grant-in-Aid of Research to help fund the processing of nutrient samples for this thesis. This research was conducted under grants from the National Science Foundation and the St. Johns Water Management District awarded to Dr. Jim Heffernan.

Thank you to my friends both in Miami and scattered across the globe for making sure I remained sane and as socially competent as any science nerd could be, and to my brother and parents for their love, support, and care packages throughout my career. I also wish to thank Aldo, with loving memory, for the years of warmth and fuzziness he brought to my life. And finally, thank you to my wonderful husband, Ewan Isherwood, for being only minimally annoyed by my working during early mornings and late nights, and for steadfastly believing in and supporting me, especially when I could not. 


\section{ABSTRACT OF THE THESIS \\ DIRECT AND INDIRECT EFFECTS OF ORGANIC MATTER SOURCES ON DENITRIFICATION IN FLORIDA RIVERS \\ by \\ Megan L. Fork}

Florida International University, 2012

Miami, Florida

Professor James Fourqurean, Major Professor

Denitrification removes large amounts of reactive nitrogen $(\mathrm{N})$ from ecosystems via reduction of nitrate to dinitrogen gas. In aquatic ecosystems, the influences of terrestrial and aquatic sources of organic matter $(\mathrm{OM})$ on denitrification are potentially complex. Terrestrially-derived OM is often less labile than autochthonous OM; it may inhibit denitrification directly via biochemical mechanisms; and it may indirectly inhibit denitrification by reducing light availability to — and thus OM exudation by-aquatic primary producers. Using a natural dissolved OM gradient among rivers of northern Florida, I investigated these mechanisms using laboratory denitrification assays subjected to factorial amendments of $\mathrm{NO}_{3}{ }^{-}$and dextrose, humic acid dosing, and cross-incubations of sediments and water. Results indicated that C-limitation increased with DOC concentrations, consistent with the indirect inhibition hypothesis. Blackwater neither depressed nor stimulated denitrification rates, indicating that this DOC neither directly inhibits nor acts as a usable OM source for denitrifiers. 


\section{TABLE OF CONTENTS}

CHAPTER

PAGE

I. Introduction ……

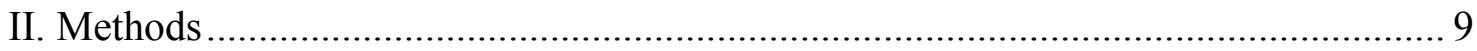

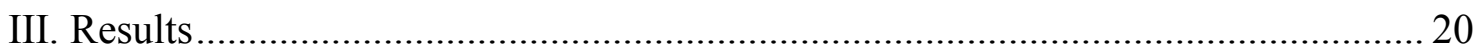

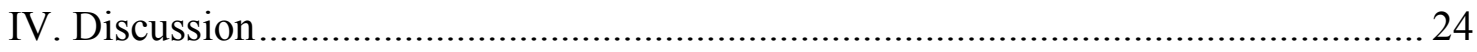

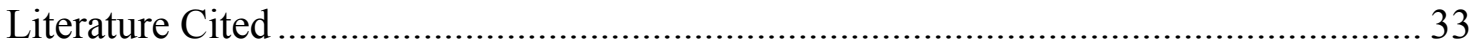

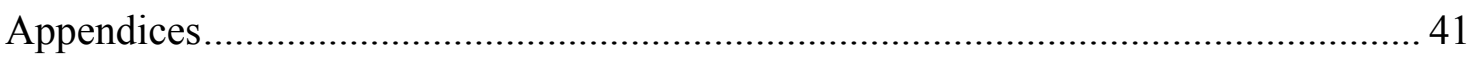




\section{LIST OF FIGURES}

FIGURE

PAGE

1. Effects of labile organic matter on denitrification rates 44

2. Effects of terrestrially derived organic matter on denitrification rates 44

3. Photographs of a spring and a blackwater river 45

4. Map of sampling sites by category 46

5. Treatments for sediment incubation experiments $\quad 47$

6. Relationships and Pearson's correlation coefficients between variables along the gradient $\quad 48$

7. Correlation between instantaneous and long-term measurements of nitrate and $\mathrm{DOC} / \mathrm{TOC}$

8. Effect of sediment organic matter $(\mathrm{OM})$ content on denitrification rate for sediments under different nutrient amendments

9. Proportional change in DOC during bioavailability incubation by site

10. Added variable plots for multiple regressions

11. Examples of results for within-site ANOVA for one spring (Ichetucknee River) and one blackwater (Cow Creek) site.

12. Denitrification rates for N-replete water substitution experiments by sediment source

14. Denitrification rates produced by $\mathrm{C}$ and $\mathrm{N}$ amendments, and response ratios of amendments along spring-blackwater gradient and against water column DOC:DIN ratio 


\section{LIST OF ABBREVIATIONS}

$\begin{array}{ll}\text { ANOVA } & \text { Analysis of variance } \\ \text { CDOM } & \text { Chromophoric (or colored) dissolved organic matter } \\ \text { DIN } & \text { Dissolved inorganic nitrogen } \\ \text { DOC } & \text { Dissolved organic carbon } \\ \text { DOM } & \text { Dissolved organic matter } \\ \text { GPP } & \text { Gross primary production } \\ \text { MIMS } & \text { Membrane inlet mass spectrometry } \\ \text { OM } & \text { Organic matter } \\ \text { t0 } & \text { Time zero - samples measured immediately } \\ \text { t6 } & \text { Time six - samples measured after six hour incubation } \\ \text { TOC } & \text { Total organic carbon (here, used as a proxy for DOC) }\end{array}$




\section{INTRODUCTION}

Concentrations of dissolved organic carbon (DOC) in inland surface waters have shown significant and widespread increases over the last two decades (Evans et al. 2005), particularly in rivers with highly organic soils in their catchments (Worrall et al. 2004, Hruška et al. 2009). Dissolved organic carbon dominates carbon export in most freshwater ecosystems, and increased export of DOC from terrestrial ecosystems could cause areas such as peatlands and arctic tundra, which currently act as carbon sinks, to become net carbon sources (Randerson et al. 2002, Worrall et al. 2004, Anderson and Stedmon 2007, Cole et al. 2007). The causes of rising DOC in inland waters concentrations are unclear, but some studies implicate increased temperature (Freeman et al. 2001, Evans et al. 2005), while others attribute increased DOC export to decreases in acidity or ionic strength (Evans et al. 2005, Aitkenhead-Peterson et al. 2009, Hruška et al. 2009). Changes in land use have also been shown to affect the quantity and mobility of soil dissolved organic matter within catchments and therefore stream DOC concentrations (Khomutova et al. 2000, Chantigny 2003, Dawson and Smith 2007).

Because DOC is linked to a wide range of ecological processes in freshwater (Prairie 2008), the ecological implications of rising DOC are likely to be diverse and significant. Increases in DOC can reduce the $\mathrm{pH}$ of surface waters (Evans et al. 2005), as some of the components of DOC are organic acids. Humic substances in DOC absorb light, altering light regimes in the water column and benthos of freshwater ecosystems (Evans et al. 2005). Dissolved organic carbon also fuels metabolism of heterotrophic bacteria, which in turn are consumed by other organisms, potentially affecting aquatic food webs (Mulholland 1997, Freeman et al. 2001, Evans et al. 2005, Cole et al. 2006). 
Changes in DOC concentration may also influence transport and toxicity of metals such as aluminum, copper, iron, (e.g., McKnight and Bencala 1990, Murphy and Zachara 1995, Dupré et al. 1999), as well as cycling of nitrogen $(\mathrm{N})$ and phosphorus (P) (see review by Sterner and Elser 2002, and Schlesinger et al. 2011).

Over the last 150 years, anthropogenic sources of fixed $\mathrm{N}$ have increased by an order of magnitude and have come to dominate the nitrogen cycle (Vitousek et al. 1997, Galloway et al. 2003, Taylor and Townsend 2010). Human production of reactive nitrogen through the Haber-Bosch process, the burning of fossil fuels, widespread cultivation of $\mathrm{N}$-fixing crops, and concentrated large-scale production of livestock have caused an imbalance in the pre-industrial equilibrium between $\mathrm{N}$-fixation and denitrification (Galloway et al. 2003). The resulting reactive nitrogen inputs have caused eutrophication, acidification, and biodiversity loss in freshwater systems (Vitousek et al. 1997, Galloway et al. 2003), hypoxic dead zones in downstream estuarine and coastal zones (Turner and Rabalais 1991), and the formation of ozone in the troposphere, which negatively impacts human health (U.S. EPA 2002, Galloway et al. 2003).

Denitrification is a heterotrophic pathway by which nitrate $\left(\mathrm{NO}_{3}{ }^{-}\right)$is reduced to nitrogen gas $\left(\mathrm{N}_{2}\right)$, coupled to the metabolic oxidation of organic matter (Canfield et al. 2010). This process represents a major pathway for the removal of reactive nitrogen by transformation into less biologically available $\mathrm{N}_{2}$ gas. During transport of $\mathrm{N}$ through river networks, denitrification can mitigate downstream impacts of reactive nitrogen by reducing the $\mathrm{N}$ load (Alexander et al. 2000, Seitzinger et al. 2006).

Rates of denitrification have three main proximate controls: the presence of anoxic conditions, of nitrate, and of bioavailable organic matter (OM) or other electron 
donors (see review by Burgin and Hamilton 2007). Where nitrate is abundant, including most streams that drain agricultural areas, the quality and quantity of organic matter generally determine denitrification rates (Pfenning and McMahon 1997, Hedin et al. 1998, Inwood et al. 2007). Organic matter not only fuels denitrification directly, but also indirectly by stimulating aerobic respiration, which enhances denitrification rates by increasing the anoxic volume in soils and sediments (Figure 1). Denitrification rates tend to increase in response to the addition of labile organic C (Pfenning and McMahon 1997, Inwood et al. 2007, but see Bernhardt and Likens 2002) and with greater organic content of sediments (e.g., Böhlke et al. 2009). Therefore, if all OM were highly labile and available to denitrifiers, a positive relationship between dissolved organic carbon and denitrification rates should result (Figure 1B).

In reality, differences in organic matter quality that result in large part from variation in source, have important implications for denitrification (Figure 2; Piña-Ochoa and Álvarez-Cobelas 2006, Inwood et al. 2007, Taylor and Townsend 2010). Because of their greater need for structural support, terrestrial plants produce organic matter that is generally more structurally complex and lower in nutrient content than that derived from aquatic primary producers (Cebrian 1999, Sterner and Elser 2002). Both C:nutrient stoichiometry and structural complexity influence bioavailability of, and thus heterotrophic demand for, DOC (Sun et al. 1997, Barnes et al. 2012). Further, the proportion of aromatic compounds (recalcitrant components of DOC that indicate degradation of structural lignin), is significantly lower in DOC produced by aquatic primary producers than allochthonous DOC (McKnight et al. 2001). Moreover, OM exported from terrestrial ecosystems is typically depleted in labile fractions that are 
consumed by soil heterotrophs before reaching waterways (McDowell and Likens 1988). Although recent studies suggest that bacterial heterotrophs consume older and more complex C compounds such as humic-like substances (Cole and Caraco 2001, Barnes et al. 2012), terrestrially-derived DOC is generally much more recalcitrant and less labile than that exuded by aquatic primary producers (e.g., Sierra et al. 1997, McKnight et al. 2001, Thorp and Delong 2002, Stedmon et al. 2003). A given concentration of terrestrially-derived DOC is therefore likely to support less denitrification than an equivalent amount derived from in situ production by aquatic vegetation (Figure 2).

In addition to its lower lability, terrestrial DOC may inhibit denitrification in aquatic systems via direct and indirect mechanisms. First, moieties such as phenolics, which are more concentrated in DOC derived from terrestrial as opposed to aquatic sources, may directly suppress denitrification (Dodla et al. 2008). Second, light-absorbent aromatic compounds such as tannic and humic acids reduce light penetration in aquatic ecosystems (Meyer 1990), thereby indirectly reducing the production of labile exudates by aquatic primary producers (Figure 2). Since the release of these labile organic compounds into the bioreactive sediments by benthic algae and macrophyte roots can fuel high rates of denitrification (Arango et al. 2007, Heffernan and Cohen 2010, Heffernan and Fisher 2012), high concentrations of chromophoric dissolved organic matter (CDOM) may indirectly suppress denitrification in aquatic ecosystems (Figure 2A). The proximate and ultimate controls on denitrification and other $\mathrm{N}$ transformations are well understood in small streams (e.g., Peterson et al. 2001, Mulholland et al. 2008), but not in larger rivers (Ensign and Doyle 2006, Tank et al. 2008). Rivers of different sizes frequently differ in carbon source and production, 
resulting in divergence in predictions about nutrient processing rates (Vannote et al. 1980). Larger rivers are deeper and have higher specific discharge than small streams (Leopold 1994), and the resulting reduced contact between the water column and reactive benthic sediments may limit N removal in large rivers (Seitzinger et al. 2002). During transport in river networks, terrestrially-derived DOC is metabolized by upstream communities (Vannote et al. 1980, Sedell et al. 1989, Leff and Meyer 1991), further reducing lability. Thus, terrestrially-derived DOC that reaches denitrifying communities in the sediments of large rivers is likely poor fuel for denitrification and other metabolic processes (but see Cole and Caraco 2001, Cole et al. 2007).

Some features of large rivers may in fact favor higher rates of denitrification than would be predicted by geometric scaling. The finer texture of large river sediments compared to that of small streams (Vannote et al. 1980) may promote higher denitrification rates (García-Ruiz et al. 1998, Solomon et al. 2009). The greater width of large rivers compared to small streams reduces shading by riparian vegetation, which results in high light availability, and can promote photodegradation of recalcitrant DOC to more labile compounds (Moran and Zepp 1997). However, photodegradation of DOC also produces compounds such as carbon monoxide (Valentine and Zepp 1993) that can inhibit bacterial denitrification enzymes (Miyata and Mori 1968). Perhaps more importantly, higher light availability fuels higher rates of primary production (Lamberti and Steinman 1997) and thus exudation of labile organic compounds into river sediments. Therefore, the importance of in situ primary production to denitrification may increase with channel size (Heffernan and Cohen 2010, Heffernan et al. 2010). These uncertainties 
arising from differences between large and small streams constrain effective modeling of $\mathrm{N}$ dynamics at river network scales (Wollheim et al. 2006, Helton et al. 2011).

\section{North Florida Rivers}

Rivers in northern Florida, USA, span a wide range of DOC concentrations, with the end members of this riverine DOC gradient represented by two distinct river types (Figure 3). Spring-fed rivers have very clear water, are hydrologically, chemically and thermally stable, and support highly productive aquatic plant communities (Odum 1957a). In contrast, blackwater rivers, like those throughout much of the southeastern U.S., are characterized by low gradients, and tannic, dark-stained water that allows minimal benthic primary production (Meyer 1990). These distinct river types and the intermediate conditions created by their mixing (Bledsoe and Phlips 2000) provide a natural environmental gradient of DOC concentration among rivers, which I used to examine the effects of carbon quantity and quality on denitrification rates.

Northern Florida contains nearly 800 named springs fed by the karstic Floridan Aquifer, of which 33 springs have nominal discharges greater than $2.8 \mathrm{~m}^{3} \mathrm{~s}^{-1}$ (firstmagnitude springs; Scott et al. 2004), giving north central Florida the greatest density of large springs in the world. Total organic carbon concentrations in the water column near spring heads are among the lowest in the world, typically below practical detection limits (Scott et al. 2004, Duarte et al. 2010). Nonetheless, long-term and high-resolution mass balance indicate that these systems support high rates of denitrification, up to $1.5 \mathrm{~g} \mathrm{~N} \mathrm{~m}^{-2}$ $\mathrm{d}^{-1}\left(0.11 \mathrm{~mol} \mathrm{~N} \mathrm{~m}^{-2} \mathrm{~d}^{-1}\right.$; Heffernan et al. 2010, Heffernan and Cohen 2010). 
Blackwater rivers are common throughout the eastern U.S. and are found throughout the world (Meyer 1990). Blackwater rivers tend to have low hydraulic gradients that generate lower average flow velocity and more variable flow than spring runs, irrespective of their geography (Meyer 1990). The dark amber-colored water results from high concentrations of fulvic acids and tannins, organic carbon compounds derived from the breakdown of terrestrial vegetation in the swamps and wetlands where these rivers originate (Meyer 1990, Sabater et al. 1993). While slow flow makes these rivers hydrologically suitable for phytoplankton communities, low light transmission through dark-colored water causes light limitation of water-column production (Phlips et al. 2000).

These spring and blackwater rivers are end members in an environmental gradient of DOC concentration among rivers. In addition to a gradient of DOC concentration, these sites also represented a gradient of organic carbon source, with sites on the spring end of the gradient containing DOC derived primarily from autochthonous primary production, while sites on the blackwater end of the gradient contained DOC mobilized from the decay of terrestrial organic matter. The intermediate section of this DOC gradient was populated by sites downstream of confluences between blackwater and spring-fed tributaries, where mixing resulted in intermediate, and potentially temporally variable, concentrations of DOC and a blend of characteristics of each end member.

As in rivers throughout the world, nitrate concentrations have increased in many northern Florida spring-fed and blackwater rivers over the last several decades (Bledsoe and Phlips 2000, Scott et al. 2004, Heffernan et al. 2010). Agricultural inputs, including synthetic fertilizer application and livestock waste are thought to be the main source of 
enrichment (Katz et al. 2005). High $\mathrm{NO}_{3}{ }^{-}$inputs to these ecosystems may lead to algae blooms as a result of eutrophication, degrading habitat quality (Vitousek et al. 1997, Galloway et al. 2003), although other factors may be primarily responsible for algal blooms in springs (Heffernan et al. 2010b). Because northern Florida springs are major recreation areas and unique ecological features, it is important to understand the limitations and controls on processes such as denitrification that remove some anthropogenic nitrate from rivers in this area.

In this study, I identified large streams and rivers in north and central Florida that span an environmental gradient of long-term organic carbon concentration and characterized how other parameters, including nitrate concentration, hydrologic variability, chlorophyll $a$, and dissolved oxygen (DO) concentration co-varied with longterm organic carbon. I also compared long-term measurements of organic carbon and nitrate concentration to instantaneous measurements on the day of sampling to identify how well the moment of sampling represented the overall chemical regime of these rivers.

Using sites arrayed along this gradient, I performed a series of experiments to test the hypothesis that organic carbon derived from terrestrial sources supports lower denitrification rates in northern Florida rivers as compared to organic carbon from aquatic sources. These experiments, including factorial amendments of labile $\mathrm{DOC}$ and $\mathrm{NO}_{3}{ }^{-}$, and substitution of overlying water from spring and blackwater sources, enabled evaluation of the possible mechanisms of lower lability, direct inhibition, and indirect inhibition as drivers of variation in denitrification rate. Specifically, if blackwater DOC were simply less labile than autochthonous DOC, a lower proportion of it would be consumed during 
bioavailability incubation, and dosing sediments with high concentrations of blackwater DOC should cause negligible stimulation of denitrification rates. Direct biochemical inhibition of denitrification by blackwater DOC, on the other hand, would result in depressed denitrification rates for spring sediments incubated with blackwater or with high doses of standardized humic/fulvic acids relative to source water control. Finally, indirect inhibition of denitrification by blackwater DOC via reduced primary production would cause an increase in severity of $\mathrm{C}$ limitation along the environmental DOC gradient, as higher concentrations of terrestrially-derived DOC more acutely attenuate light and inhibit autochtonous production of labile organic compounds. These experiments allowed me to identify the mechanisms, operating alone or in combination, through which carbon quality affects denitrification in large Florida rivers.

\section{METHODS}

In order to test the hypothesis that terrestrial DOC supports lower denitrification rates than aquatic DOC, and to distinguish among possible mechanisms, I identified study sites in north-central Florida rivers which encompassed a wide gradient of DOC concentrations. I performed incubations to measure differences in DOC bioavailability along the gradient. Water and sediment samples from these sites were used to perform denitrification assays which I used to identify differences in $\mathrm{C}$ and $\mathrm{N}$ limitation of denitrification rates. A DOC dosing experiment was used to determine if terrestrial DOC at near- and higher-than-observed concentrations was directly inhibitory to denitrification rates. These observations and experiments allowed me to draw conclusions about the 
effects and mechanisms of differences in denitrification rate in rivers with different DOC sources and concentrations.

\section{Site selection}

Using satellite images (Google Earth - http://www.google.com/earth/index.html) and data from the EPA STORET (www.epa.gov/storet/) database, I identified 20 study sites representing an environmental gradient of DOC concentration in north and central Florida, USA (Table $1 \&$ Figure 4). Sites were located in Florida's Central Lake and Ocala Uplift physiographic districts, which are generally characterized by sandhill and sand pine scrub communities, and mixed hardwood, pine flatwood, and sandhill communities, respectively (Myers and Ewel 1990). Precipitation regimes in north and central Florida are moderately seasonal with higher rates in summer, and temperature ranges from a summer mean of $27-30^{\circ} \mathrm{C}$ to winter mean of about $15-17^{\circ} \mathrm{C}$ (Myers and Ewel 1990).

\section{DOC gradient}

I used data available from the St. John's, Suwannee River, and Southwest Florida Water Management Districts, and EPA STORET databases to describe long-term means of total organic carbon (TOC) and other solutes for each study site. Total organic carbon was used as a proxy for DOC, because DOC data were less prevalent in the databases. For intermediate and blackwater categories, I used only sites with available data that spanned multiple seasons for at least two years between 2000 and 2011 to calculate the long term means (the minimum number of data points used to characterize long-term 
mean TOC was for the Alexander River at County Road 445 where five records were taken in five distinct seasons between 2000-2001). For spring sites, the criterion for data that spanned all seasons was relaxed because of lower availability of TOC data for springs, and the fact that these systems tend to exhibit quite stable discharge and water chemistry among seasons (Odum 1957b). These 20 sites made up an environmental gradient of long-term TOC concentration that ranged from 0.2 to $36 \mathrm{mg} \mathrm{C} \mathrm{L}^{-1}(0.017$ to $\left.3.0 \mathrm{mmol} \mathrm{C} \mathrm{L}^{-1}\right)$.

Relationships among long-term nitrate concentration, coefficient of variation of long-term discharge, mean water column chlorophyll $a$, and the slope of the relationship between dissolved oxygen (DO) and time of day were analyzed to further characterize the environmental TOC gradient and how nitrate, hydrology and primary production co-vary with TOC in north Florida rivers. I also measured sediment OM content and assessed its covariation with long-term TOC along the environmental gradient. Long-term TOC and nitrate data were compared with instantaneous DOC and nitrate from samples, respectively, collected on the same day as sediment and surface water for denitrification assays to determine how well instantaneous measurements represent overall DOC and nitrate regimes in these river systems.

Some analyses required that sites be categorized as blackwater, spring or intermediate on the basis of long-term average TOC concentration and analysis of major confluences upstream of site locations (Table 1). Sites located downstream of a confluence between a spring and blackwater stream were labeled "intermediate," while only sites without major visible inputs (in satellite imagery and online Google or Bing maps) of another type were categorized as "spring" or "blackwater". Because site 
categories were assigned on the basis of upstream inputs and long-term TOC, site categories do not match exactly to the TOC gradient (Cow Creek, a BW site has a slightly lower long-term average TOC than the Withlacoochee River at Hwy 48, an intermediate site; Table 1).

\section{Field collections and water chemistry analyses}

From each site, I collected approximately $2 \mathrm{~kg}$ of the top $5 \mathrm{~cm}$ of benthic sediment in five replicates; , the stratum in which $90 \%$ of benthic denitrification occurs (Inwood et al. 2007). Sediment samples were stored on ice until returned to the laboratory. I also collected approximately $40 \mathrm{~L}$ of river water (for treatment solutions) with a peristaltic pump and $0.45 \mu \mathrm{m}$ in-line filter, reserving $250 \mathrm{~mL}$ of filtered water for laboratory analysis of DOC, nitrate/nitrite, ammonium, and soluble reactive phosphorus (SRP). Water samples for nutrient analysis were stored on ice during transport, and frozen immediately upon return to the lab. Nutrient analyses were performed in the Southeast Environmental Research Center (SERC) Nutrient Analysis Laboratory by flow injection analysis using an ALPKEM RFA 300 autoanalyzer (Alpkem Corp., Clackamas, Oregon). Standard U.S. EPA methods (1993) were used to measure concentrations of nitrate/nitrite (method 353.2), SRP (method 365.1) and ammonium (method 350.1). Concentration of DOC was measured according to USGS standard operating procedure NU-062 using a Shimadzu TOC-5000 (Shimadzu Corp., Kyoto, Japan). A YSI 556 Sonde (YSI Inc., Yellow Springs, Ohio) equipped with an optical probe was used to measure dissolved oxygen (DO), $\mathrm{pH}$, specific conductivity and water temperature at the time of sediment sampling. 
Upon return to the laboratory, sediments were stored at $4^{\circ} \mathrm{C}$ until assays were performed. Sediments were brought to room temperature overnight in order to allow microbial communities to acclimatize and regain activity before analysis (Herrman et al. 2008), and were homogenized in collection bags before being split for the denitrification assay. All denitrification assays were performed within six days of sediment collection.

\section{Bioavailability}

A subset of four sites was used to analyze DOC bioavailability in surface water and sediment porewater among site categories. The subset used for bioavailability incubations included one blackwater site (Blackwater Creek at Hwy 44, "BWC44"), one spring-fed site (Wekiva Run upstream of major surface water inputs, "Weku") and two intermediate sites (Wekiva River downstream of confluence with Rock Springs run, "Wekd"; Wekiva River at Katie's Landing, "WekKL”). From each site, four unfiltered replicates of surface water were collected in $500 \mathrm{~mL}$ brown plastic bottles. I also collected three one-kg replicates of the upper $5 \mathrm{~cm}$ of benthic sediment (Inwood et al. 2007). Surface water and benthic sediment samples were immediately placed on ice until return to the laboratory, and then transferred to storage at $4{ }^{\circ} \mathrm{C}$. Surface water samples were vacuum-filtered through a $0.2 \mu \mathrm{m}$ polycarbonate filter within one week of collection to remove particulates and bacteria (Qualls and Haines 1992), and then frozen until analysis. Sediment pore-water was extracted using a sintered glass vacuum filtration device, and then filtered and stored in the same manner as surface water.

An inoculant was prepared by mixing $100 \mathrm{~g}$ of sediment from each of the four sites and adding tap water to bring total volume to $1 \mathrm{~L}$ (Qualls and Haines 1992). The 
inoculant was held at room temperature and kept oxygenated with constantly bubbled air. Water was replenished periodically to keep total volume at approximately $1 \mathrm{~L}$. Inoculant was prepared for the incubations by removing $20 \mathrm{~mL}$ from the stock flask after thoroughly agitating, and then filtered through a $0.2 \mu \mathrm{m}$ polycarbonate filter. Filtrate was discarded and the inoculant and filter paper were immediately added to each flask for bioavailability incubation (Qualls and Haines 1992).

To assess differences in bioavailability of DOC among sites, I measured initial DOC in surface water and porewater, and compared these to DOC concentration after five day incubation. Bioavailability incubations were prepared using $300 \mathrm{~mL}$ of surface or porewater that was pre-filtered and thawed to room temperature. Prepared inoculant was then added to this water. Flasks were continuously oxygenated and kept at room temperature for the duration of the 5-day incubation (Qualls and Haines 1992, Barnes et al. 2012).

\section{Sediment organic matter content}

After performing denitrification assays, sediment samples were dried to constant mass and sediment organic matter (OM) content determined as loss on ignition. Dry sediment sub-samples were homogenized in BOD bottles before being transferred to precombusted aluminum pans. I determined the ash-free dry mass of four sediment subsamples per sampling location (both time zero and time six for incubations measuring ambient and potential rates) by measuring and recording sample mass before and after combustion at $550^{\circ} \mathrm{C}$ for five hours. Organic matter content ranged from $0.1 \%$ in sediment taken from Withlacoochee at River Rd (WithRiv) to 85\% at Wekiwa Springs 
run (Weku); the OM content among sampling locations within sites also varied considerably (Table 1).

\section{Denitrification assays}

I performed three different denitrification assay experiments, each using similar methodology but different treatments, to assess $\mathrm{C}$ and $\mathrm{N}$ limitation of and the effects of terrestrially-derived DOC on denitrification rates. For each experiment, I added approximately $100 \mathrm{~g}$ of wet, homogenized sediment to $300 \mathrm{~mL}$ BOD bottles, or approximately $30 \mathrm{~g}$ of sediment to $60 \mathrm{~mL}$ BOD bottles, excluding particles too large to fit into the neck of the bottle. For each sampling site, two complete sets of treatments were constructed, with one set measured at time zero (T0) and one set measured after approximately six hours of incubation (T6). Treatment solutions were added at room temperature using a siphon to minimize contact with the atmosphere, and bottles were overfilled so that air was excluded. Solutions were not deoxygenated before incubation experiments. I stoppered bottles, and then inverted them several times to remove any air pockets from the sediment. Bottles were then partially refilled from the bottom of the water layer, just above the sediment, to remove bubbles. During incubation, bottles were kept in darkness and inverted once per hour to avoid diffusion limitation of nitrate supply to the sediment.

I used membrane inlet mass spectrometry (MIMS) to measure dissolved $\mathrm{N}_{2}$ concentrations (Kana et al. 1994). Membrane inlet mass spectrometry measures dissolved gases directly from water samples, avoiding artefacts associated with the acetylene block technique for conducting denitrification assays (Groffman et al. 2006). In order to reduce 
the effect of $\mathrm{O}_{2}$ interference with $\mathrm{N}_{2}$ measurements, a copper reduction column heated to $600{ }^{\circ} \mathrm{C}$ removed $\mathrm{O}_{2}$ from samples before measurement (Eyre et al. 2002). I used humidatmosphere-equilibrated deionized water in three $1 \mathrm{~L}$ spherical vessels, incubated with stirring in high-precision water baths $\left( \pm 0.01^{\circ} \mathrm{C}\right)$ at $10.0,17.0$, and $24.0^{\circ} \mathrm{C}$ for at least 24 hours prior to analysis, as standards for $\mathrm{N}_{2}$ (Heffernan et al. 2012). Hamme and Emerson's (2004) solubility formulas were used to calculate gas concentrations in each standard according to its temperature. Signal strength at each mass was recorded every five seconds, and signal values for samples and standards were determined as the mean value of measurements for the first stable full minute of measurements. A standard curve was run every 4-6 samples to account for instrument drift, and I applied interpolated parameter values to estimate gas concentrations in each sample (Heffernan et al. 2012).

Time zero measurements were made immediately by directly sampling supernatant water using the MIMS intake. These measurements were then subtracted from the $\mathrm{T} 6$ measurements to determine the change in $\mathrm{N}_{2}$ concentration over the incubation period. Measurements for T0 and T6 cannot be taken from the same bottle because of potential contamination by atmospheric $\mathrm{N}_{2}$ introduced as headspace during $\mathrm{T} 0$ sampling. After sampling of supernatant water, sediment was dried until constant mass, and masses recorded.

I used the difference in $\mathrm{N}_{2}$ gas concentration for each pair, incubation time, and sediment mass and organic matter content to determine denitrification rates ( $\mu \mathrm{g} \mathrm{N} \mathrm{g}$ sediment $\left.\mathrm{OM}^{-1} \mathrm{hr}^{-1}\right)$. These denitrification assay methods were used to conduct three different experiments: 
DOC dosing: To address possible direct inhibitory effects of DOC concentrations outside of the range of DOC concentrations observed in the field, I performed a dosing experiment with standard humic and fulvic acids sourced by the International Humic Substances Society (IHSS). Both sediment and water from each of a high-, medium-, and low-nitrate spring (Manatee, Ichetucknee, and Alexander Springs, respectively) were collected, as specified above. Treatment solutions consisted of unamended site water as a controland humic acid at concentrations of $50 \mathrm{mg} \mathrm{C} \mathrm{L}^{-1}\left(4.2 \mathrm{mmol} \mathrm{C} \mathrm{L}^{-1}\right.$; similar to the highest DOC concentration observed in the field) and $150 \mathrm{mg} \mathrm{L}^{-1}\left(12.5 \mathrm{mmol} \mathrm{C} \mathrm{L}^{-1}\right.$; approximately triple the highest observed DOC).

Factorial $\mathrm{C}$ and $\mathrm{N}$ amendment assays: Treatment solutions for factorial amendment denitrification assays (Figure 5) used ambient local river water collected on the day of sampling and consisted of four treatments: Control ( 0 ; unamended river water), nitrate (N) river water plus $1 \mathrm{mmol}$ nitrate), carbon (C; river water plus $1 \mathrm{mmol}$ dextrose), and carbon-nitrate ( $\mathrm{CN}$; river water plus $1 \mathrm{mmol}$ nitrate and $1 \mathrm{mmol}$ dextrose).

Water substitutions: Water source substitution incubations (Figure 5) were conducted using water from both spring and blackwater rivers. Sediments from spring end members were incubated with overlying site water as the control (0) treatment, as well as with water from the nearest blackwater site from the same river system. The converse was true of sediments from blackwater rivers, while sediments collected from intermediate points along the gradient were incubated with both spring (S) and blackwater (BW). These substitution incubations allowed me to assess lability and direct inhibition by blackwater DOC as mechanisms responsible for limitation of denitrification rates in each of these types of rivers. I also analyzed unamended, unfiltered water 
samples without sediment for 11 sites to measure the contribution to total denitrification occurring within the water column.

\section{Statistical methods}

I used Pearson's correlation coefficients and simple linear regression to assess covariation of parameters along the environmental long-term total organic carbon gradient.

For each treatment, I assessed the influence of log-transformed sediment organic matter content on log-transformed denitrification rates using simple linear regression, once for each factorial amendment treatment. Before analysis, I omitted outliers with Cook's distance greater than 1 (one outlier each in control, $\mathrm{N}$ only, and $\mathrm{CN}$ treatments). In addition, I analyzed the effect of sediment OM content on subset of denitrification rates including only positive values (no outliers). Because sediment OM exerts strong control on the denitrification rate (Figure 7), I analyzed treatment effects from DOC dosing, source water substitution, and limitation assays based on OM-corrected rates ( $\mu \mathrm{g}$ $\mathrm{Ng}$ sed $\left.\mathrm{OM}^{-1} \mathrm{hr}^{-1}\right)$.

To understand the broad controls on denitrification in large north and central Florida rivers, I used all-subsets regression analysis to determine predictive models for both ambient (control treatment) and potential (CN treatment) log-transformed denitrification rates. The input parameters in the model selection process were: long-term TOC, instantaneous DOC, long-term nitrate, instantaneous nitrate, sediment organic content, and hydrologic variability (measured as $\mathrm{CV}$ of long-term discharge). Adjusted $r^{2}$ was used to choose an appropriate final model. I used simple linear regression to assess 
the importance of nitrate as a predictor for both ambient and potential denitrification rates. A linear regression of the residuals of a model with the nitrate parameter removed against the residuals of a model using the remaining parameters to predict measured nitrate (added variable plot) was constructed, with the slope of the relationship indicating the importance of the nitrate parameter to the final model.

I used two-way analysis of variance (ANOVA) to compare the effects of factorial $\mathrm{C}$ and $\mathrm{N}$ amendments within each site (Table 3), using a Box-Cox transformation of rates prior to analysis. The effects of humic acid dosing on log-transformed denitrification rates, as well as differences in raw and proportional changes in DOC concentration during bioavailability incubations, were also assessed using analysis of variance. Nonparametric ANOVA on the ranked denitrification rates was used for water substitution experiments. Welch's t-test was also used to compare the N-replete treatments for spring and blackwater substitutions and verify results from the all-treatment non-parametric analysis of variance. When significant differences in treatment effects were detected, I used Tukey's HSD to identify distinct means.

To compare how treatment effects and $\mathrm{C}$ and $\mathrm{N}$ limitation of denitrification rates were related to the ratio of DOC to dissolved inorganic nitrogen (DIN), and how rates changed along the gradient of DOC or TOC, I performed functional data analysis (Ramsay and Silverman 2002). Using within-site mean denitrification rates for each treatment (Table 3), I calculated response ratios (N:control, C:control, $\mathrm{CN}: \mathrm{C}$, and $\mathrm{CN}: \mathrm{N})$, then regressed these ratios against DOC:DIN, long-term TOC (for $\mathrm{CN}: \mathrm{N}$ and $\mathrm{C}$ :control ratios only), or long-term nitrate (for $\mathrm{CN}$ : $\mathrm{C}$ and $\mathrm{N}$ :control ratios only). Negative values of response ratio were omitted prior to log-transformation, as ratios are particularly sensitive 
to the magnitude of a frame shift required to log-transform (two negative values removed from each of $\mathrm{C}$ : control and $\mathrm{CN}$ : $\mathrm{C}$ response ratios).

I used R version 2.11.1 with the GUI R-Studio and packages "leaps" and "MASS" to perform all statistical analyses.

\section{RESULTS}

Denitrification rates measured in the control (ambient rates) in this study ranged from $0.001 \mu \mathrm{g} \mathrm{N} \mathrm{g} \mathrm{sed}{ }^{-1} \mathrm{hr}^{-1}\left(0.071 \mathrm{nmol} \mathrm{N} \mathrm{g} \mathrm{sed}^{-1} \mathrm{hr}^{-1}\right)$ in the Santa Fe River near Hwy 121 (SF121), to $3.615 \mu \mathrm{g} \mathrm{N} \mathrm{g} \mathrm{sed}^{-1} \mathrm{hr}^{-1}\left(258 \mathrm{nmol} \mathrm{N} \mathrm{g} \mathrm{sed}^{-1} \mathrm{hr}^{-1}\right)$ in the upstream Wekiva River (Weku), with a mean of $0.517 \mu \mathrm{g} \mathrm{N} \mathrm{g} \mathrm{sed}{ }^{-1} \mathrm{hr}^{-1}\left(37 \mathrm{nmol} \mathrm{N} \mathrm{g} \mathrm{sed}^{-1} \mathrm{hr}^{-1}\right.$; Table 3). Denitrification rates in the $\mathrm{CN}$ treatments, which represent potential rates, ranged from $0.107 \mu \mathrm{g} \mathrm{N} \mathrm{g} \mathrm{sed}{ }^{-1} \mathrm{hr}^{-1}\left(7.6 \mathrm{nmol} \mathrm{N} \mathrm{g} \mathrm{sed}^{-1} \mathrm{hr}^{-1}\right)$ in the Withlacoochee River at River Rd (WithRiv), to $6.966 \mu \mathrm{g} \mathrm{N} \mathrm{g} \mathrm{sed}{ }^{-1} \mathrm{hr}^{-1}$ (498 $\mathrm{nmol} \mathrm{N} \mathrm{g} \mathrm{sed}^{-1} \mathrm{hr}^{-1}$ ) in the Wekiva River downstream of its confluence with Rock Spring run (Wekd), with a mean of $2.042 \mu \mathrm{g} \mathrm{N} \mathrm{g}$ $\operatorname{sed}^{-1} \mathrm{hr}^{-1}$ (146 nmol N g sed ${ }^{-1} \mathrm{hr}^{-1}$; Table 3).

While hydrology showed strong covariation along the TOC gradient, nitrate covaried only weakly with long-term TOC. Mean water column chlorophyll $a$ and the slope of DO vs. time of day (metrics of water column and ecosystem primary production, respectively) showed clear relationships, though opposite in sign, with long-term TOC (Figure 6). The coefficient of variation of long-term discharge (a measure of hydrologic variability) and long-term TOC were strongly positively correlated (adjusted $\mathrm{r}^{2}=0.82, p$ $<0.001$ ), while long-term and instantaneous measures of nitrate concentration exhibit a negative, though not statistically significant relationship with long-term TOC (long-term 
nitrate: $p=0.13$, instantaneous nitrate: $p=0.10$ ). Mean water column chlorophyll $a$ concentration was positively correlated with long-term TOC (adjusted $r^{2}=0.16, p$ $<0.001$ ), while the slope of DO vs. time of day and long-term TOC were negatively correlated (adjusted $\mathrm{r}^{2}=0.32, p<0.001$ ). Instantaneous measurements of DOC and nitrate correlate strongly with long-term TOC (adjusted $r^{2}=0.76, p<0.001$ ) and nitrate (adjusted $\left.r^{2}=0.60, p<0.001\right)$, respectively, exhibiting a slope near one (Figure 7).

Organic matter content of the sediment explained between 16 and $65 \%$ of the variation in denitrification rates measured in the control, $\mathrm{N}$ only and $\mathrm{C}$ and $\mathrm{N}$ treatments, while there was no significant relationship between denitrification rate and sediment $\mathrm{OM}$ in the $\mathrm{C}$ only treatment (Table 2). When negative values of denitrification rate were removed from analysis, the observed relationship between sediment OM and denitrification rate was much stronger, and explained a higher portion of variation in the data, ranging from 38 to $65 \%$. For each of the regressions with a significant result, sediment OM content and denitrification rates were positively correlated (Figure 8). The relationship was more pronounced in the N-replete treatments ( $\mathrm{CN}$ and $\mathrm{N}$ only) than in the treatments in which sediments were subject to $\mathrm{N}$-limitation (control and $\mathrm{C}$ only).

Measured net change in DOC concentration in the bioavailability incubations was not consistently positive or negative, and did not differ significantly among the four sites measured ( $p=0.11$, data not shown). Change in DOC concentration as a proportion of starting DOC concentration also did not differ significantly among sites $(p=0.32$; Figure 9). Two replicates (one each from BWC44 and WekKL) showed an increase in DOC concentration of more than an order of magnitude. These results were considered erroneous and were excluded from the analysis. 
All-subsets regression analysis indicated that the best fit model for ambient (adjusted $\left.r^{2}=0.44, p<0.001\right) \log$-transformed denitrification rates contained the parameters: sediment organic matter content $(\mathrm{OM})$, long-term TOC, instantaneous nitrate concentration, and hydrologic variability (Table 2). The best-fit regression for logtransformed denitrification potentials (adjusted $r^{2}=0.69, p<0.001$ ) contained the same parameters, but used long-term rather than instantaneous nitrate concentration (Table 2). An added variable plot (Figure 10) allowed assessment of the importance of the nitrate parameter in absence of bias caused by its co-variation with the other parameters. Here, the residuals of the linear model relating instantaneous nitrate to TOC, OM and hydrologic variability explained $14 \%$ of the variation in residuals from the model relating ambient denitrification (control treatment) rate to these same parameters and had a slope of 0.85 . For the potential model ( $\mathrm{CN}$ treatment), the same analysis indicated that the long-term nitrate model residuals did not explain a significant amount of variation in the residuals of the denitrification rate model $(p=0.56)$.

Within-site ANOVAs (Table 3) showed strong evidence for nitrate limitation of denitrification rates in 16 of 20 sites. Treatments containing $\mathrm{N}$ as nitrate showed significantly higher rates than N-unamended treatments (Figure 11). None of the sites showed evidence of carbon limitation alone. Furthermore, two sites showed a significant interaction effect between carbon and nitrate amendments. In Cow Creek, a blackwater site, the effects of adding $\mathrm{C}$ and $\mathrm{N}$ together were approximately additive of the effects of either $\mathrm{C}$ or $\mathrm{N}$ alone, indicating co-limitation of the denitrifying bacterial community by both labile carbon and nitrate (Figure 11). 
Water substitution had no significant effect on denitrification rates for any combination of sediment and water source (for blackwater sediments, $p=0.65$; intermediate sediments, $p=0.60$; spring sediments, $p=0.53$; Figure 12 ). Dosing with high concentrations of humic acid neither significantly depressed nor increased denitrification rates in any sediment type ( $p=0.84$; Figure 13$)$. Water column denitrification assays showed no significant differences between $\mathrm{T} 0$ and $\mathrm{T} 6 \mathrm{~N}_{2}$ concentrations in any of the 11 sites measured, suggesting negligible contribution of the water column to denitrification (data not shown).

Regressions of denitrification rate (expressed per gram sediment OM) against long-term TOC were not significant for any treatment (Figure 14-A, B), but in all cases the highest values were observed in systems with low TOC. Long-term TOC was not correlated with denitrification rates from the $\mathrm{CN}$ treatment $(p=0.94)$. The denitrification rates for the $\mathrm{N}$-only treatment had a slightly negative relationship with long-term TOC, but this was not significant $(p=0.15)$. Similarly, neither rates measured in the $\mathrm{C}$ treatment $(p=0.47)$ nor the control treatment $(p=0.24)$ were correlated with long-term TOC.

In contrast, treatment response ratios were correlated with the ratio of DOC:DIN in the water column, as well as long-term nitrate and TOC concentrations (Figure 14). The response ratio of C:control and water column DOC:DIN were not significantly correlated ( $p=0.12 ;$ Figure 14-C), but when one outlier was removed, a weakly significant positive correlation between C:control ratio and DOC:DIN was observed ( $p=$ 0.09). The relationship between $\mathrm{CN}: \mathrm{N}$ ratio and DOC:DIN was also weakly significant and positive ( $p=0.07$; Figure 14-D). A negative linear relationship between the 
$\mathrm{N}$ :control response ratio and long-term nitrate concentration explained $30 \%$ of the variation in N:control ratio ( $p=0.02$; Figure 14-H). Similarly, the regression of $\mathrm{CN}: \mathrm{C}$ against long-term nitrate concentration was significant and negative $(p=0.24$; Figure 14$\mathrm{G})$. The ratio of C:control vs. TOC was not significant $(p=0.44)$, however, when one outlier was omitted, the relationship between C:control and TOC was significantly positive ( $p=0.004$ ), with TOC explaining $40 \%$ of the variation in the C:control ratio (Figure 14-E). The ratio of $\mathrm{CN}: \mathrm{N}$ response against long-term TOC was positive, and described $44 \%$ of variation in the $\mathrm{CN}: \mathrm{N}$ response ratio $(p=0.002$; Figure 14-F).

\section{DISCUSSION}

I observed an increase in the response of denitrification rates to labile $\mathrm{C}$ addition along a TOC gradient, which is consistent with increased C-limitation at higher concentrations of terrestrial DOC. The results of my study suggest that direct inhibition is negligible at both ambient and elevated concentrations of DOC characteristic of Florida's blackwater rivers and that this terrestrially-derived organic matter is also largely unsuitable to fuel denitrification. These results are consistent with the hypothesis that DOC from terrestrial sources indirectly inhibits denitrification rates by limiting light to the benthos and thus excludes autochothonous production in highly colored rivers.

In the northern Florida rivers included in my study, long-term TOC and nitrate concentrations covaried only slightly (Figure 6). Because the covariation was relatively weak, it is likely that observed variation in denitrification rates among sites along the TOC gradient are relatively independent of nitrate concentrations. I observed good 
agreement between long-term and instantaneous measurements of both nitrate and DOC/TOC.

Positive correlation between long term TOC and the slope of DO vs. time of day further indicates that primary production is limited in systems with high concentrations of DOC in the water column. In highly productive river reaches, photosynthesis increases DO concentrations over the course of the day, while in rivers with low production, the effects of diel temperature variation decreases the solubility of $\mathrm{O}_{2}$ in the afternoon when water temperatures are higher. Aerobic metabolism also decreases DO concentration (Odum 1956). Therefore, analyzing the slope of DO against time of day gives information about the relative magnitude of ecosystem primary production among systems. If DOC controls production, then the slope of DO vs. time of day should decrease with increasing DOC, as observed in my study (Figure 6).

Particularly in intermediate sites, which integrate different proportions of water from blackwater and spring-fed rivers among seasons, long-term and instantaneous water quality measurements give different information. Long-term mean and variance in a water quality parameter may determine the composition of the bacterial community, while the instantaneous measurements quantify the absolute and relative abundance of reactants available to denitrifiers. Therefore, both types of data are valuable as they can elucidate timescales over which DOC and nitrate are important for a given biogeochemical process. In my study, measurements of carbon and nitrate correlate well between the two timescales, indicating that instantaneous measurements taken during sediment sampling are representative of the long term DOM and nitrate regimes in these systems. 
The results of my study suggest that the dark-colored and high-molecular-weight dissolved organic carbon characteristic of blackwater rivers neither directly inhibits nor stimulates denitrification rates. Neither incubating sediments from spring or intermediate rivers with water from blackwater sources, nor dosing any sediment type with high levels of humic acid resulted in significant change in denitrification rates under N-replete or ambient $\mathrm{N}$ concentration conditions. I did not observe any significant differences in bioavailability of DOC among site types, but my results cannot separate effects of DOC consumption and production during incubations. High variability in these data suggests that the bioavailability assay performed poorly. Nevertheless, incubation with blackwater and humic acid did not increase denitrification rates, indicating that blackwater DOC is not a labile carbon source for denitrifiers. Together, these results suggest that the DOC in blackwater systems does not directly inhibit denitrification rates, but this DOC has little metabolic benefit for denitrifying bacteria.

Correlations between response ratios of experimental treatments and long-term TOC concentration provide evidence of indirect inhibition of denitrification by terrestrial dissolved organic carbon. The C:control response ratio, higher values of which indicate greater carbon limitation, was positively related to long-term TOC concentration, indicating greater severity of carbon limitation of denitrification in systems with greater DOC, as predicted by the indirect inhibition hypothesis. In contrast, the N:control response ratio decreases with increasing nitrate concentration, indicating that nitrate limitation is less severe in systems with higher background nitrate concentrations. The increase in C limitation with increasing DOC is observed both in sediments that are subject to $\mathrm{N}$-limitation (C:control ratio) as well as those subjected to N-replete conditions 
(CN:N ratio), indicating that DOC-driving $\mathrm{C}$ limitation is independent of nitrate concentration. Increased severity of C limitation in blackwater as opposed to spring sites is also observed in the comparison of treatment effects between individual sites (Figure 11). In the Ichetucknee River, a spring site, the pattern of responses to treatments indicates nitrate-only limitation. In contrast, the pattern of denitrification treatment responses in sediments from Cow Creek, a blackwater site, suggests that the denitrifier community is co-limited by nitrate and labile $\mathrm{C}$ in this blackwater site.

The conclusion that blackwater dissolved organic carbon inhibits denitrification rates indirectly through suppression of aquatic primary production is consistent with the conclusions drawn by Heffernan and Cohen (2010) from the results of high-frequency measurements of nitrate in the Ichetucknee River, one of northern Florida's spring runs. They attributed approximately $80 \%$ of total $\mathrm{N}$ removal in this system to denitrification. Much of the day-to-day variation in $\mathrm{N}$ removal ascribed to denitrification was explained by variation in gross primary production (GPP), which was, in turn, linked to changes in insolation, indicating tight coupling between primary production and denitrification in this system. The most likely mechanism for this coupling of primary production and $\mathrm{N}$ removal is alleviation of C-limitation following days of high insolation as a result of increased exudation of labile DOC by primary producers (Heffernan and Cohen 2010).

I have shown evidence that inhibition of denitrification in higher DOC sites is a result of increased C-limitation resulting from light limitation of primary production. However, long-term TOC concentrations and hydrologic variability are highly correlated (Figure 5), which confounds the reason for exclusion of aquatic vegetation as a source of labile carbon from blackwater rivers. If these ecological communities are sensitive to 
variable flow and river stage, hydrologic variability may play a role in their absence. However, some study sites with relatively high hydrologic variability had established benthic vegetation communities (e.g., With48, WekKL), suggesting that hydrologic variability alone is not sufficient to exclude submerged aquatic vegetation communities. Both colored DOC and hydrologic variability likely play a role in limiting primary production. Even in oligotrophic lakes, light limitation by DOC is the primary control on primary productivity (Karlsson et al. 2009). While it is likely that light limitation of photosynthesis by colored DOC is the primary constraint on labile $\mathrm{C}$ availability, future studies should address the contributions of flow regime to limitation of macrophyte communities in Florida rivers.

Measurements of absorption and fluorescence spectra of a DOC pool provide a great deal of information regarding the relative proportion of different moieties within the pool (e.g., Sierra et al. 1997, McKnight et al. 2001, Stedmon et al. 2003), but the significance of these optical properties to ecological function is less clear (Jaffé et al. 2008). The roles of DOC in an aquatic ecosystem are varied (Jaffé et al. 2008) and, different components within the DOC pool interact, as shown in my study. Further application of spectroscopic methods to link these measurements of DOC composition to specific ecological functions will strengthen understanding of the many and interacting roles DOC plays in aquatic ecosystems.

The denitrification rates observed in this study fall within the wide range reported from acetylene block measurements in other systems. The mean ambient rate for sediment incubations from all sites used in this study was $0.517 \mu \mathrm{g} \mathrm{N} \mathrm{g} \mathrm{sed}{ }^{-1} \mathrm{hr}^{-1}(37$ $\mathrm{nmol} \mathrm{N} \mathrm{g} \mathrm{sed}{ }^{-1} \mathrm{hr}^{-1}$ ), very similar to the mean reported by Barnes et al. (2012) of $0.696 \mu \mathrm{g}$ 
$\mathrm{N} \mathrm{g} \mathrm{sed}{ }^{-1} \mathrm{hr}^{-1}\left(50 \mathrm{nmol} \mathrm{N} \mathrm{g} \mathrm{sed}{ }^{-1} \mathrm{hr}^{-1}\right)$ for Boulder Creek (Colorado, USA) and its tributaries. Arango et al. (2007) report a range of ambient denitrification rates in Midwestern streams with varying benthic substrates from 0.1 to $11.1 \mu \mathrm{g} \mathrm{N} \mathrm{g} \mathrm{sed}{ }^{-1} \mathrm{hr}^{-1}$ ( 7.1 to $793 \mathrm{nmol} \mathrm{N} \mathrm{g} \mathrm{sed}{ }^{-1} \mathrm{hr}^{-1}$ ). Similarly, Groffman et al. (2005) measured ambient denitrification rates in urban streams of Baltimore, MD, which ranged from $0.0026 \mu \mathrm{g} \mathrm{N}$ $\mathrm{g} \mathrm{sed}^{-1} \mathrm{hr}^{-1}\left(0.19 \mathrm{nmol} \mathrm{N} \mathrm{g} \mathrm{sed}^{-1} \mathrm{hr}^{-1}\right)$ in gravel bed sediment to $4.96 \mu \mathrm{g} \mathrm{N} \mathrm{g} \mathrm{sed}^{-1} \mathrm{hr}^{-1}$ (354 nmol $\mathrm{N} \mathrm{g} \mathrm{sed}{ }^{-1} \mathrm{hr}^{-1}$ ) in substrate from a debris dam. As in this study, Groffman et al. (2005) found that denitrification rates were strongly correlated with sediment organic matter content.

Because denitrification incubations were conducted ex situ, the ambient and potential rates measured in these experiments may not be representative of actual rates in these systems. Removing sediments from the rivers, transporting and homogenizing them before incubation, exposes anoxic sediments to the atmosphere and destroys its structure . Removal of sediment for experimentation may also disrupt the effects of exudation by macrophyte and microphytobenthic communities. The approach used in this study, while useful for identifying limitations and potential rates of denitrification, also isolates sediments from any effects of flow. In natural river systems, advection continuously delivers dissolved nitrate and carbon (but see Cohen et al. 2012 for discussion of nitrate diffusion limitation of denitrification in these systems), but in my experiment, diffusion and hourly manual mixing of incubation vessels were the only means of nitrate delivery to sediments during incubation. In addition, during transport and storage of water and sediment, labile DOC in the water column or in interstitial water of sediment samples may have been metabolized by organisms that passed through filtering of water or were 
collected with sediments. Finally, oxic conditions present at the beginning of denitrification incubation experiments could have led to competition between denitrifiers and aerobes for available nitrate.

In many cases, the effects of these bottle experiment artefacts would be to mask rather than exaggerate expected treatment effects. Changes in nitrate availability and delivery in the incubations as compared to in situ conditions should be manifest equally among sites, and should not impose a directional change in observed rates. If labile DOC were consumed during transport and storage of water and sediment, then the likelihood of C-limitation should increase in sediments from conditions that favored production of labile $\mathrm{C}$ by primary producers. Even given this possible masking effect of consumption of labile C, I still observed a pattern of increasing $\mathrm{C}$ limitation with increasing DOC. Competition between denitrifiers and aerobes during oxic periods of incubations, particularly in the carbon-only treatment, may explain the negative denitrification rates measured in several carbon-only treatment incubations, and again, should serve to mask differences in severity of $\mathrm{C}$ limitation along the DOC gradient of rivers.

Despite the limitations of bottle experiments, the ambient denitrification rates I observed have good agreement with long-term, high-resolution mass balance estimates of denitrification in one spring river system (Heffernan et al. 2010, Heffernan and Cohen 2010). Heffernan et al. (2010) used a mass balance approach to calculate areal denitrification rates of 23.8 to $32.1 \mathrm{mg} \mathrm{N} \mathrm{m}^{-2} \mathrm{~h}^{-1}\left(1.70\right.$ to $\left.2.29 \mathrm{mmol} \mathrm{N} \mathrm{m}^{-2} \mathrm{~h}^{-1}\right)$ for the Ichetucknee River. Using a bulk density value of $1.21 \mathrm{~g} \mathrm{~cm}^{-3}$ for sediment of this river (R. Hensley, pers. comm.), I created a conversion factor for mass-based to areal rates, assuming an active denitrifying layer of depth $5 \mathrm{~cm}$ (Inwood et al. 2007). I used the mean 
ambient denitrification rate for the Ichetucknee River of $0.378 \mu \mathrm{g} \mathrm{N} \mathrm{g} \mathrm{sed}{ }^{-1} \mathrm{hr}^{-1}$ (27 nmol $\mathrm{N} \mathrm{g} \mathrm{sed}{ }^{-1} \mathrm{hr}^{-1}$; Table 3) to calculate an areal rate of $22.9 \mathrm{mg} \mathrm{N} \mathrm{m}^{-2} \mathrm{~h}^{-1}\left(1.64 \mathrm{mmol} \mathrm{N} \mathrm{m}^{-2} \mathrm{~h}^{-}\right.$ $\left.{ }^{1}\right)$ - very similar to the mass-balance estimate. The denitrification rate measured for the Ichetucknee River also falls in the range of areal denitrification rates measured using MIMS to measure denitrification by the open-channel method, which measures $\mathrm{N}_{2}$ production in situ over whole river reaches. Laursen and Seitzinger (2002) used the openchannel method to measure denitrification rates in three rivers in the U.S. and observed a wide range from $3.8 \mathrm{mg} \mathrm{N} \mathrm{m}^{-2} \mathrm{~h}^{-1}\left(0.27 \mathrm{mmol} \mathrm{N} \mathrm{m}^{-2} \mathrm{~h}^{-1}\right)$ to $221.3 \mathrm{mg} \mathrm{N} \mathrm{m}^{-2} \mathrm{~h}^{-1}(15.81$ mmol $\mathrm{N} \mathrm{m}^{-2} \mathrm{~h}^{-1}$ ). The rate I measured in the Ichetucknee River using an ex situ incubation, is well within the range of denitrification rates measured in situ by Laursen and Seitzinger, further supporting the denitrification rates measured using this technique.

\section{Implications for $N$ cycling in large rivers}

Most of the current methods for estimating $\mathrm{N}$ removal processes in large rivers involve scaling measurements made in small headwater streams to the channel geometry and hydrology of large rivers (Alexander et al. 2000, Seitzinger et al. 2002). This approach, however, underestimates $\mathrm{N}$ removal in some large rivers because it deemphasizes the importance of in situ OM production, which tends to be a more important carbon source in large rivers than headwater streams (Heffernan et al. 2010). The results of this study support the assertion made by Heffernan et al. (2010) that scaling derived from hydrology and geometry alone, particularly in rivers with highly productive submerged aquatic vegetation communities, is insufficient to predict the magnitude of $\mathrm{N}$ removal in large rivers. 
Some physical characteristics of large streams, such as finer sediments and higher light levels, suggest that they provide more suitable conditions for denitrification (Lamberti and Steinman 1997, Moran and Zepp 1997, Solomon et al. 2009) than small streams, while other properties, such as greater depth and a higher proportion of recalcitrant OM (Vannote et al. 1980, Leff and Meyer 1991, Seitzinger et al. 2002) suggest the opposite. What is clear is that large rivers and small streams are not the same, and conclusions about coupling of $\mathrm{C}$ and $\mathrm{N}$ cycles derived from small streams should not simply be scaled up to explain the behavior of biogeochemical cycles in large rivers. In large rivers, especially those with clear water, autochthonous production is an important source of labile carbon for denitrifiers. Explicitly clarifying the role of these large rivers in freshwater denitrification will allow for more accurate global $\mathrm{N}$ budgets and predictions about the response of $\mathrm{C}$ and $\mathrm{N}$ cycles in the face of global change.

My study elucidates how global nitrogen cycling changes with rising concentrations of DOC in surface waters. My results suggest the quantity and quality of DOC in rivers of Florida are linked, and that blackwater rivers with high concentrations of DOC not only contain a high proportion of recalcitrant compounds, but also that attenuation of light by colored DOC inhibits the production of more labile compounds produced by aquatic vegetation. Denitrification is likely to become more carbon limited as concentrations of colored DOC increase in surface waters, diminishing the ability of freshwater ecosystems to remove reactive nitrogen. By inhibiting in stream primary production and production of labile OM in the sediments, increases in colored DOC in freshwater ecosystems may have consequences not only for the ecology and biogeochemistry of those systems, but also for eutrophication of downstream ecosystems. 


\section{LITERATURE CITED}

Aitkenhead-Peterson, J., M. Steele, N. Nahar, and K. Santhy. 2009. Dissolved organic carbon and nitrogen in urban and rural watersheds of south-central Texas: Land use and land management influences. Biogeochemistry 96:119-129.

Alexander, R. B., R. A. Smith, and G. E. Schwarz. 2000. Effect of stream channel size on the delivery of nitrogen to the Gulf of Mexico. Nature 403:758-761.

Anderson, N. J., and C. A. Stedmon. 2007. The effect of evapoconcentration on dissolved organic carbon concentration and quality in lakes of SW Greenland. Freshwater Biology 52:280-289.

Arango, C. P., J. L. Tank, J. L. Schaller, T. V. Royer, M. J. Bernot, and M. B. David. 2007. Benthic organic carbon influences denitrification in streams with high nitrate concentration. Freshwater Biology 52:1210-1222.

Barnes, R. T., R. L. Smith, and G. R. Aiken. 2012. Linkages between denitrification and dissolved organic matter quality, Boulder Creek watershed, Colorado. Journal of Geophysical Research 117:14 PP.

Bernhardt, E., and G. Likens. 2002. Dissolved organic carbon enrichment alters nitrogen dynamics in a forest stream. Ecology 83:1689-1700.

Bledsoe, E., and E. Phlips. 2000. Relationships between phytoplankton standing crop and physical, chemical, and biological gradients in the Suwannee River and plume region, U.S.A. Estuaries and Coasts 23:458-473.

Böhlke, J. K., R. C. Antweiler, J. W. Harvey, A. E. Laursen, L. K. Smith, R. L. Smith, and M. A. Voyte. 2009. Multi-scale measurements and modeling of denitrification in streams with varying flow and nitrate concentration in the upper Mississippi River basin, USA. Biogeochemistry 93:117-141.

Burgin, A. J., and S. K. Hamilton. 2007. Have we overemphasized the role of denitrification in aquatic ecosystems? A review of nitrate removal pathways. Frontiers in Ecology and the Environment 5:89-96.

Canfield, D. E., A. N. Glazer, and P. G. Falkowski. 2010. The evolution and future of Earth's nitrogen cycle. Science 330:192-196.

Cebrian, J. 1999. Patterns in the fate of production in plant communities. American Naturalist 154:449-468. 
Chantigny, M. H. 2003. Dissolved and water-extractable organic matter in soils: A review on the influence of land use and management practices. Geoderma 113:357-380.

Cohen, M. J., J. B. Heffernan, A. Albertin, and J. B. Martin. 2012. Inference of riverine nitrogen processing from longitudinal and diel variation in dual nitrate isotopes. Journal of Geophysical Research-Biogeosciences 117:G01021.

Cole, J., and N. Caraco. 2001. Carbon in catchments: Connecting terrestrial carbon losses with aquatic metabolism. Marine and Freshwater Research 52:101-110.

Cole, J. J., S. R. Carpenter, M. L. Pace, V. de Bogert, M. C, J. L. Kitchell, and J. R. Hodgson. 2006. Differential support of lake food webs by three types of terrestrial organic carbon. Ecology Letters 9:558-568.

Cole, J. J., Y. T. Prairie, N. F. Caraco, W. H. McDowell, L. J. Tranvik, R. G. Striegl, C. M. Duarte, P. Kortelainen, J. A. Downing, J. J. Middelburg, and J. Melack. 2007. Plumbing the global carbon cycle: Integrating inland waters into the terrestrial carbon budget. Ecosystems 10:171-184.

Dawson, J. J. C., and P. Smith. 2007. Carbon losses from soil and its consequences for land-use management. Science of The Total Environment 382:165-190.

Dodla, S. K., J. J. Wang, R. D. DeLaune, and R. L. Cook. 2008. Denitrification potential and its relation to organic carbon quality in three coastal wetland soils. Science of the Total Environment 407:471-480.

Duarte, C. M., Y. T. Prairie, T. K. Frazer, M. V. Hoyer, S. K. Notestein, R. Martinez, A. Dorsett, and D. E. Canfield. 2010. Rapid accretion of dissolved organic carbon in the springs of Florida: The most organic-poor natural waters. Biogeosciences 7:4051-4057.

Dupré, B., J. Viers, J.-L. Dandurand, M. Polve, P. Bénézeth, P. Vervier, and J.-J. Braun. 1999. Major and trace elements associated with colloids in organic-rich river waters: ultrafiltration of natural and spiked solutions. Chemical Geology 160:6380.

Ensign, S. H., and M. W. Doyle. 2006. Nutrient spiraling in streams and river networks. Journal of Geophysical Research 111:G04009.

Evans, C. D., D. T. Monteith, and D. M. Cooper. 2005. Long-term increases in surface water dissolved organic carbon: Observations, possible causes and environmental impacts. Environmental Pollution 137:55-71. 
Eyre, B. D., S. Rysgaard, T. Dalsgaard, and P. B. Christensen. 2002. Comparison of isotope pairing and $\mathrm{N}_{2}$ :Ar methods for measuring sediment denitrification Assumptions, modifications, and implications. Estuaries 25:1077-1087.

Freeman, C., C. Evans, D. Monteith, B. Reynolds, and N. Fenner. 2001. Export of organic carbon from peat soils. Nature 412:785-785.

Galloway, J. N., J. D. Aber, J. W. Erisman, S. P. Seitzinger, R. W. Howarth, E. B. Cowling, and B. J. Cosby. 2003. The nitrogen cascade. Bioscience 53:341-356.

Groffman, P. M., M. A. Altabet, J. K. Bohlke, K. Butterbach-Bahl, M. B. David, M. K. Firestone, A. E. Giblin, T. M. Kana, L. P. Nielsen, and M. A. Voytek. 2006. Methods for measuring denitrification: Diverse approaches to a difficult problem. Ecological Applications 16:2091-2122.

Groffman, P. M., A. M. Dorsey, and P. M. Mayer. 2005. N Processing within Geomorphic Structures in Urban Streams. Journal of the North American Benthological Society 24:613-625.

Hamme, R. C., and S. R. Emerson. 2004. The solubility of neon, nitrogen and argon in distilled water and seawater. Deep-Sea Research Part I-Oceanographic Research Papers 51:1517-1528.

Hedin, L. O., J. C. von Fischer, N. E. Ostrom, B. P. Kennedy, M. G. Brown, and G. P. Robertson. 1998. Thermodynamic constraints on nitrogen transformations and other biogeochemical processes at soil-stream interfaces. Ecology 79:684-703.

Heffernan, J. B., A. R. Albertin, M. L. Fork, B. G. Katz, and M. J. Cohen. 2012. Denitrification and inference of nitrogen sources in the karstic Floridan Aquifer. Biogeosciences 9:1671-1690.

Heffernan, J. B., and M. J. Cohen. 2010. Direct and indirect coupling of primary production and diel nitrate dynamics in a subtropical spring-fed river. Limnology and Oceanography 55:677-688.

Heffernan, J. B., M. J. Cohen, T. K. Frazer, R. G. Thomas, T. J. Rayfield, J. Gulley, J. B. Martin, J. J. Delfino, and W. D. Graham. 2010. Hydrologic and biotic influences on nitrate removal in a subtropical spring-fed river. Limnology and Oceanography 55:249-263.

Heffernan, J. B., and S. G. Fisher. 2012. Plant-microbe interactions and nitrogen dynamics during wetland establishment in a desert stream. Biogeochemistry 107:379-391. 
Helton, A. M., G. C. Poole, J. L. Meyer, W. M. Wollheim, B. J. Peterson, P. J. Mulholland, E. S. Bernhardt, J. A. Stanford, C. Arango, L. R. Ashkenas, L. W. Cooper, W. K. Dodds, S. V. Gregory, R. O. Hall, S. K. Hamilton, S. L. Johnson, W. H. McDowell, J. D. Potter, J. L. Tank, S. M. Thomas, H. M. Valett, J. R. Webster, and L. Zeglin. 2011. Thinking outside the channel: Modeling nitrogen cycling in networked river ecosystems. Frontiers in Ecology and the Environment 9:229-238.

Herrman, K., V. Bouchard, and R. Moore. 2008. Factors affecting denitrification in agricultural headwater streams in Northeast Ohio, USA. Hydrobiologia 598:305314.

Hruška, J., P. Krám, W. H. McDowell, and F. Oulehle. 2009. Increased dissolved organic carbon (DOC) in central European streams is driven by reductions in ionic strength rather than climate change or decreasing acidity. Environmental Science and Technology 43:4320-4326.

Inwood, S. E., J. L. Tank, and M. J. Bernot. 2007. Factors controlling sediment denitrification in midwestern streams of varying land use. Microbial Ecology $53: 247-258$.

Jaffé, R., D. McKnight, N. Maie, R. Cory, W. H. McDowell, and J. L. Campbell. 2008. Spatial and temporal variations in DOM composition in ecosystems: The importance of long-term monitoring of optical properties. Journal of Geophysical Research 113:G04032.

Kana, T. M., C. Darkangelo, M. D. Hunt, J. B. Oldham, G. E. Bennett, and J. C. Cornwell. 1994. Membrane Inlet Mass-Spectrometer for rapid high-precision determination of $\mathrm{N}_{2}, \mathrm{O}_{2}$, and $\mathrm{Ar}$ in environmental water samples. Analytical Chemistry 66:4166-4170.

Karlsson, J., P. Byström, J. Ask, P. Ask, L. Persson, and M. Jansson. 2009. Light limitation of nutrient-poor lake ecosystems. Nature 460:506-509.

Katz, B., R. Copeland, T. Greenhalgh, R. Ceryak, and W. Zwanka. 2005. Using multiple chemical indicators to assess sources of nitrate and age of groundwater in a karstic spring basin. Environmental \& Engineering Geoscience 11:333-346.

Khomutova, T. E., L. T. Shirshova, S. Tinz, W. Rolland, and J. Richter. 2000. Mobilization of DOC from sandy loamy soils under different land use (Lower Saxony, Germany). Plant and Soil 219:13-19.

Lamberti, G. A., and A. D. Steinman. 1997. A comparison of primary production in stream ecosystems. Journal of the North American Benthological Society 16: 95104. 
Laursen, A. E., and S. P. Seitzinger. 2002. Measurement of denitrification in rivers: an integrated, whole reach approach. Hydrobiologia 485:67-81.

Leff, L. G., and J. L. Meyer. 1991. Biological availability of dissolved organic-carbon along the Ogeechee River. Limnology and Oceanography 36:315-323.

Leopold, L. B. 1994. A View of the River. Harvard University Press.

McDowell, W. H., and G. E. Likens. 1988. Origin, composition, and flux of dissolved organic-carbon in the Hubbard Brook Valley. Ecological Monographs 58:177195.

McKnight, D. M., and K. E. Bencala. 1990. The chemistry of iron, aluminum and dissolved organic material in 3 acidic, metal-enriched mountain streams, as controlled by watershed and in-stream processes. Water Resources Research 26:3087-3100.

McKnight, D. M., E. W. Boyer, P. K. Westerhoff, P. T. Doran, T. Kulbe, and D. T. Andersen. 2001. Spectrofluorometric characterization of dissolved organic matter for indication of precursor organic material and aromaticity. Limnology and Oceanography 46:38-48.

Meyer, J. L. 1990. A Blackwater Perspective on Riverine Ecosystems. Bioscience 40:643-651.

Miyata, M., and T. Mori. 1968. Studies on Denitrification: VIII. Production of nitric oxide by denitrifying reaction in the presence of tetramethyl-P-phenylenediamine. Journal of Biochemistry 64:849-861.

Moran, M., and R. Zepp. 1997. Role of photoreactions in the formation of biologically labile compounds from dissolved organic matter. Limnology and Oceanography 42:1307-1316.

Mulholland, P. J. 1997. Dissolved organic matter concentration and flux in streams. Journal of the North American Benthological Society 16:131-141.

Mulholland, P. J., A. M. Helton, G. C. Poole, R. O. Hall, S. K. Hamilton, B. J. Peterson, J. L. Tank, L. R. Ashkenas, L. W. Cooper, C. N. Dahm, W. K. Dodds, S. E. G. Findlay, S. V. Gregory, N. B. Grimm, S. L. Johnson, W. H. McDowell, J. L. Meyer, H. M. Valett, J. R. Webster, C. P. Arango, J. J. Beaulieu, M. J. Bernot, A. J. Burgin, C. L. Crenshaw, L. T. Johnson, B. R. Niederlehner, J. M. O’Brien, J. D. Potter, R. W. Sheibley, D. J. Sobota, and S. M. Thomas. 2008. Stream denitrification across biomes and its response to anthropogenic nitrate loading. Nature 452:202-207. 
Murphy, E. M., and J. M. Zachara. 1995. The role of sorbed humic substances on the distribution of organic and inorganic contaminants in groundwater. Geoderma 67:103-124.

Myers, R. L., and J. J. Ewel (Eds.). 1990. Ecosystems of Florida. University Press of Florida.

Odum, H. T. 1956. Primary production in flowing waters. Limnology and Oceanography $1: 102-117$.

Odum, H. T. 1957a. Primary production measurements in eleven Florida springs and a marine turtle-grass community. Limnology and Oceanography 2:85-97.

Odum, H. T. 1957b. Trophic structure and productivity of Silver Springs, Florida. Ecological Monographs 27:55-112.

Peterson, B. J., W. M. Wollheim, P. J. Mulholland, J. R. Webster, J. L. Meyer, J. L. Tank, E. Marti, W. B. Bowden, H. M. Valett, A. E. Hershey, W. H. McDowell, W. K. Dodds, S. K. Hamilton, S. Gregory, and D. D. Morrall. 2001. Control of nitrogen export from watersheds by headwater streams. Science 292:86-90.

Pfenning, K. S., and P. B. McMahon. 1997. Effect of nitrate, organic carbon, and temperature on potential denitrification rates in nitrate-rich riverbed sediments. Journal of Hydrology 187:283-295.

Phlips, E. J., M. Cichra, F. J. Aldridge, J. Jembeck, J. Hendrickson, and R. Brody. 2000. Light availability and variations in phytoplankton standing crops in a nutrient-rich backwater river. Limnology and Oceanography 45:916-929.

Piña-Ochoa, E., and M. Álvarez-Cobelas. 2006. Denitrification in aquatic environments: A cross-system analysis. Biogeochemistry 81:111-130.

Prairie, Y. T. 2008. Carbocentric limnology: Looking back, looking forward. Canadian Journal of Fisheries and Aquatic Sciences 65:543-548.

Qualls, R., and B. Haines. 1992. Biodegradability of dissolved organic-matter in forest throughfall, soil solution, and stream water. Soil Science Society of America Journal 56:578-586.

Ramsay, J. O., and B. W. Silverman. 2002. Applied Functional Data Analysis, 1st edition. Springer.

Randerson, J., F. Chapin, J. Harden, J. Neff, and M. Harmon. 2002. Net ecosystem production: A comprehensive measure of net carbon accumulation by ecosystems. Ecological Applications 12:937-947. 
Sabater, F., J. Meyer, and R. Edwards. 1993. Longitudinal patterns of dissolved organic carbon concentration and suspended bacterial density along a blackwater river. Biogeochemistry 21:73-93.

Schlesinger, W. H., J. J. Cole, A. C. Finzi, and E. A. Holland. 2011. Introduction to coupled biogeochemical cycles. Frontiers in Ecology and the Environment 9:5-8.

Scott, T. M., G. H. Means, R. P. Meegan, R. C. Means, S. B. Upchurch, J. J. Copeland, T. Roberts, and A. Willet. 2004. Bulletin No. 66: Springs of Florida. Florida Geological Survey.

Seitzinger, S., J. A. Harrison, J. K. Böhlke, A. F. Bouwman, R. Lowrance, B. Peterson, C. Tobias, and G. V. Drecht. 2006. Denitrification across landscapes and waterscapes: A synthesis. Ecological Applications 16:2064-2090.

Seitzinger, S. P., R. V. Styles, E. W. Boyer, R. B. Alexander, G. Billen, R. W. Howarth, B. Mayer, and N. van Breemen. 2002. Nitrogen retention in rivers: Model development and application to watersheds in the northeastern U.S.A. Biogeochemistry 57-58:199-237.

Sierra, M., O. Donard, and M. Lamotte. 1997. Spectral identification and behaviour of dissolved organic fluorescent material during estuarine mixing processes. Marine Chemistry 58:51-58.

Solomon, C. T., E. R. Hotchkiss, J. M. Moslemi, A. J. Ulseth, E. H. Stanley, R. O. Hall, and A. S. Flecker. 2009. Sediment size and nutrients regulate denitrification in a tropical stream. Journal of the North American Benthological Society 28:480490.

Stedmon, C., S. Markager, and R. Bro. 2003. Tracing dissolved organic matter in aquatic environments using a new approach to fluorescence spectroscopy. Marine Chemistry 82:239-254.

Sterner, R. W., and J. J. Elser. 2002. Ecological Stoichiometry: The biology of elements from molecules to the biosphere. Princeton University Press.

Sun, L., E. M. Perdue, J. L. Meyer, and J. Weis. 1997. Use of elemental composition to predict bioavailability of dissolved organic matter in a Georgia river. Limnology and Oceanography 42:714-721.

Tank, J. L., E. Rosi-Marshall, M. A. Baker, and R. O. Hall. 2008. Are rivers just big streams? A pulse method to quantify nitrogen demand in a large river. Ecology 89:2935-2945. 
Taylor, P. G., and A. R. Townsend. 2010. Stoichiometric control of organic carbonnitrate relationships from soils to the sea. Nature 464:1178-1181.

Thorp, J. H., and M. D. Delong. 2002. Dominance of autochthonous autotrophic carbon in food webs of heterotrophic rivers. Oikos 96:543-550.

Turner, R. E., and N. N. Rabalais. 1991. Changes in Mississippi River water quality this century. BioScience 41:140-147.

U.S. EPA. 1993. Methods for the Determination of Inorganic Substances in Environmental Samples, 1st edition. US EPA, Cincinnati, Ohio.

U.S. EPA. 2002. Nitrogen: multiple and regional impacts. U.S. Environmental Protection Agency, Clean Air Markets Division.

Valentine, R. L., and R. G. Zepp. 1993. Formation of carbon monoxide from the photodegradation of terrestrial dissolved organic carbon in natural waters. Environmental Science and Technology 27:409-412.

Vannote, R. L., G. W. Minshall, K. W. Cummins, J. R. Sedell, and C. E. Cushing. 1980. The river continuum concept. Canadian Journal of Fisheries and Aquatic Sciences $37: 130-137$.

Vitousek, P. M., J. D. Aber, R. W. Howarth, G. E. Likens, P. A. Matson, D. W. Schindler, W. H. Schlesinger, and D. G. Tilman. 1997. Human alteration of the global nitrogen cycle: Sources and consequences. Ecological Applications 7:737750 .

Wollheim, W. M., C. J. Voosmarty, B. J. Peterson, S. P. Seitzinger, and C. S. Hopkinson. 2006. Relationship between river size and nutrient removal. Geophysical Research Letters 33:L06410.

Worrall, F., T. Burt, and J. Adamson. 2004. Can climate change explain increases in DOC flux from upland peat catchments? Science of The Total Environment 326:95-112. 


\section{APPENDICES}

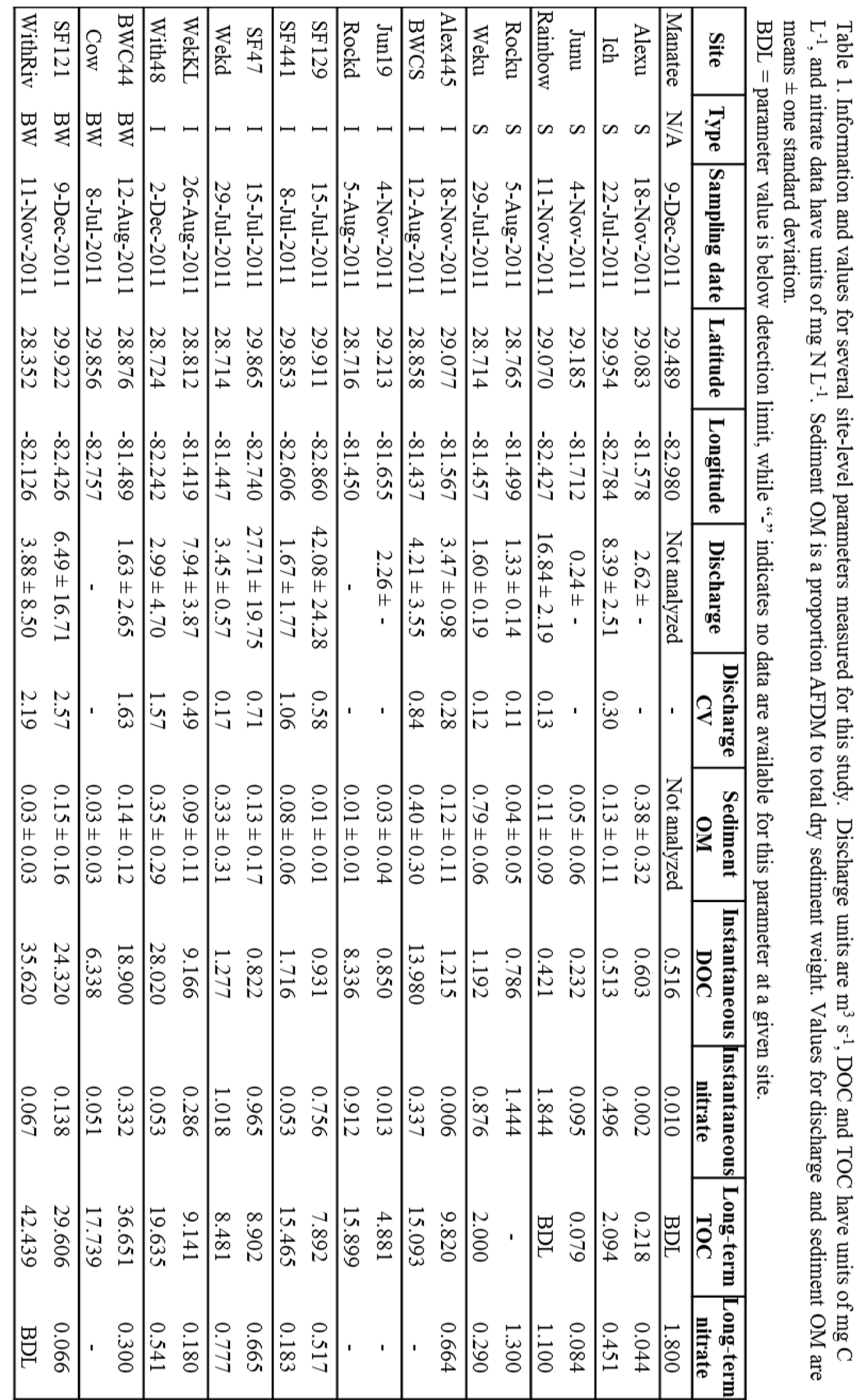


Table 2. Linear regressions of organic matter (A) and multiple regression models (B) of denitrification rate in north and central Florida rivers. Values on left (A) describe regressions of denitrification rate vs. sediment $\mathrm{OM}$ content by treatment with outliers removed, while values on right describe same regressions on a subset of only positive measured rates. The best fit multiple regression model for denitrification rates (B) for ambient and potential rates included four parameters each, and described much of the variation in measured rates.

*For ambient rates, the instantaneous measurements were used as the nitrate parameter, while the model predicting potential rates used long-term average nitrate concentrations.

\begin{tabular}{|c|c|c|c|c|c|c|}
\hline \multicolumn{7}{|c|}{ A. OM vs. rate, by treatment } \\
\hline Treatment & $\log (\mathrm{OM})$ & intercept & $\mathbf{r}^{2}$ & $\log (\mathrm{OM})$ & intercept & $\mathbf{r}^{2}$ \\
\hline control & 0.27 & 0.30 & 0.16 & 0.79 & 0.64 & 0.43 \\
\hline C only & \multicolumn{3}{|c|}{ Not significant $(p=0.42)$} & 0.58 & -0.36 & 0.38 \\
\hline N only & 0.90 & 2.07 & 0.51 & 0.89 & 2.04 & 0.52 \\
\hline $\mathrm{CN}$ & 0.93 & 2.52 & 0.65 & 0.93 & 2.52 & 0.65 \\
\hline \multicolumn{7}{|c|}{ B. Models for ambient and potential denitrification rate } \\
\hline Rate type & $\log (\mathbf{O M})$ & TOC & nitrate* & $\begin{array}{l}\text { hydrologic } \\
\text { variability }\end{array}$ & intercept & adj. $\mathrm{r}^{2}$ \\
\hline Ambient +0.31 & 0.33 & 0.12 & 0.86 & -1.74 & -0.14 & 0.44 \\
\hline Potential & 0.72 & 0.12 & -0.21 & -1.55 & 2.11 & 0.69 \\
\hline
\end{tabular}




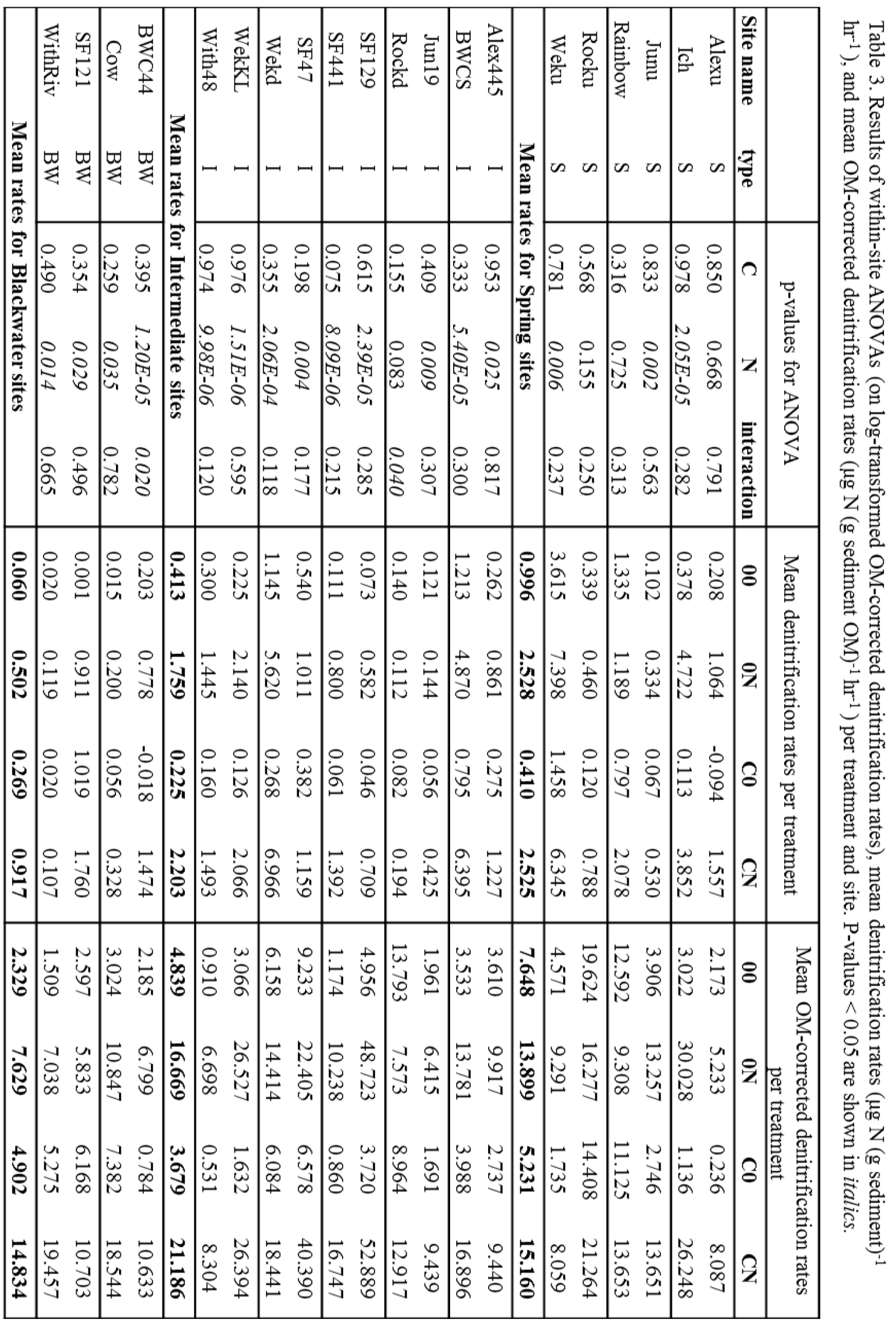




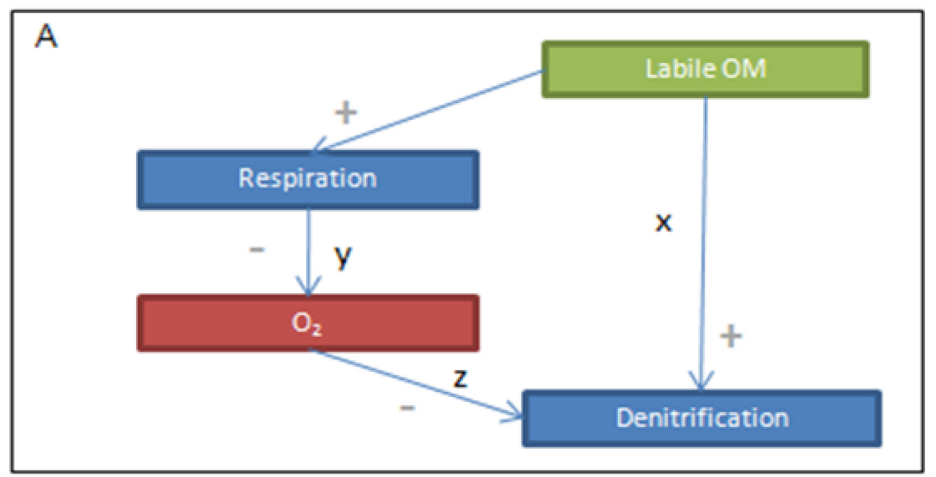

Figure 1. Effects of labile organic matter on denitrification rates. Labile OM directly fuels denitrification $(\mathrm{A}, \mathrm{x})$ and aerobic respiration, which draws down $\mathrm{O}_{2}$ concentrations (y), decreasing $\mathrm{O}_{2}$ inhibition of denitrification (z). Increases in concentrations of labile DOC should lead to increases in denitrification rates.
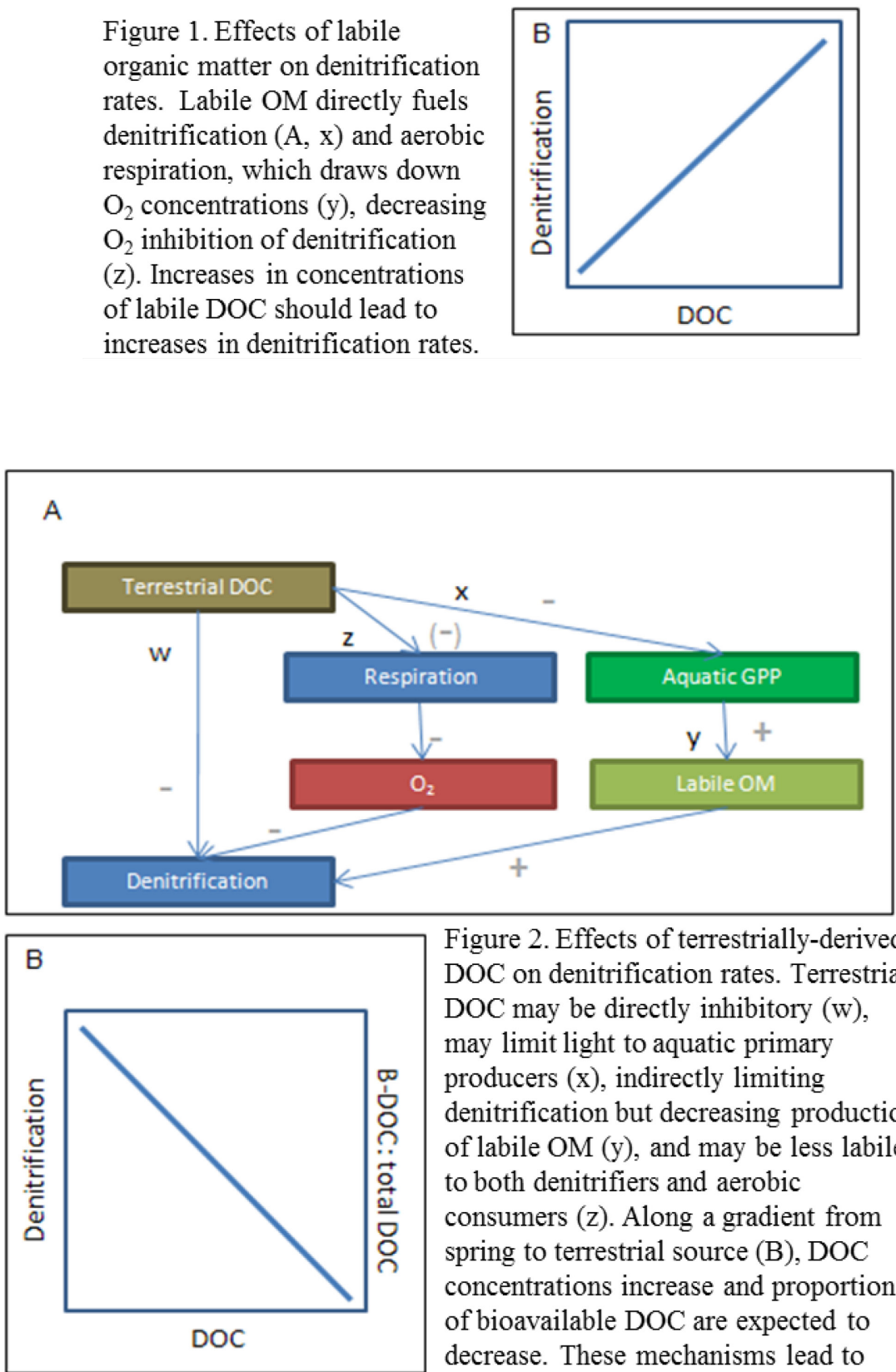

Figure 2. Effects of terrestrially-derived DOC on denitrification rates. Terrestrial DOC may be directly inhibitory (w), may limit light to aquatic primary producers (x), indirectly limiting denitrification but decreasing production of labile OM (y), and may be less labile to both denitrifiers and aerobic consumers (z). Along a gradient from spring to terrestrial source (B), DOC concentrations increase and proportion of bioavailable DOC are expected to decrease. These mechanisms lead to decreases in dentrification rates. 

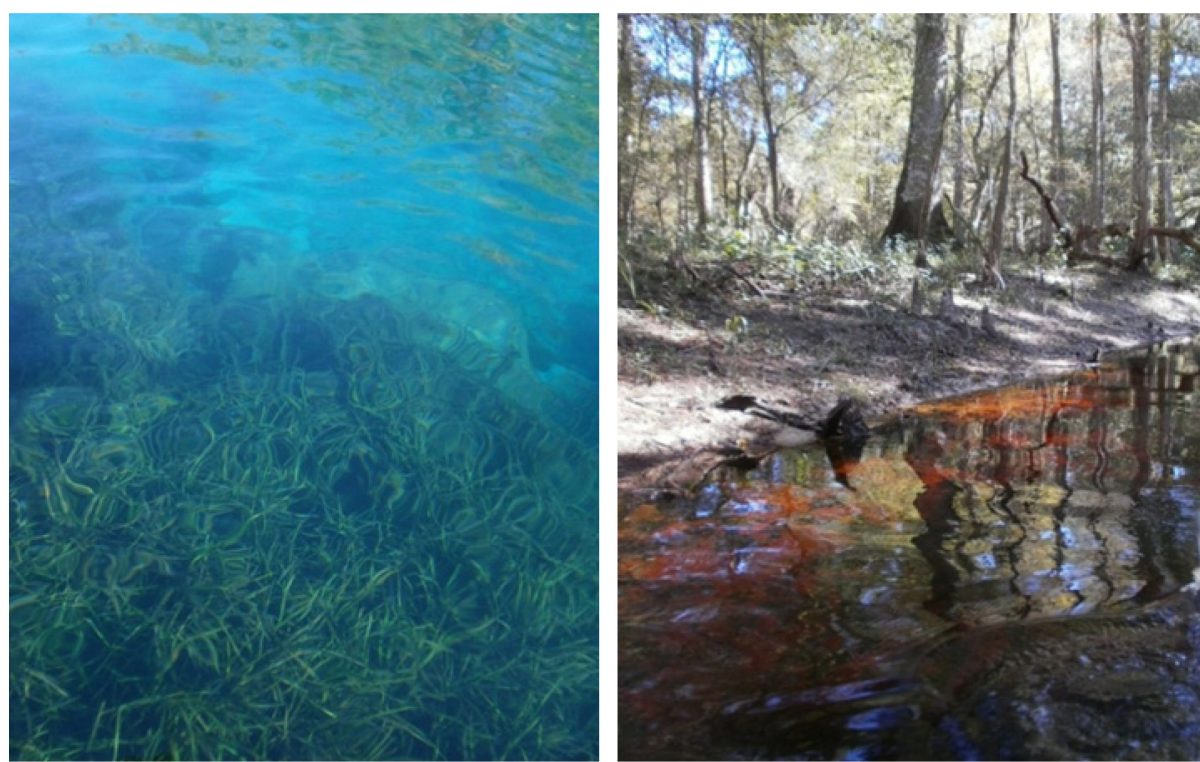

Figure 3. Photographs of a spring and a blackwater river. Rainbow springs (left), a large spring-fed river, has very clear water and supports dense growth of submerged aquatic vegetation. The Withlacoochee River (right) is a blackwater river that supports minimal aquatic vegetation. 


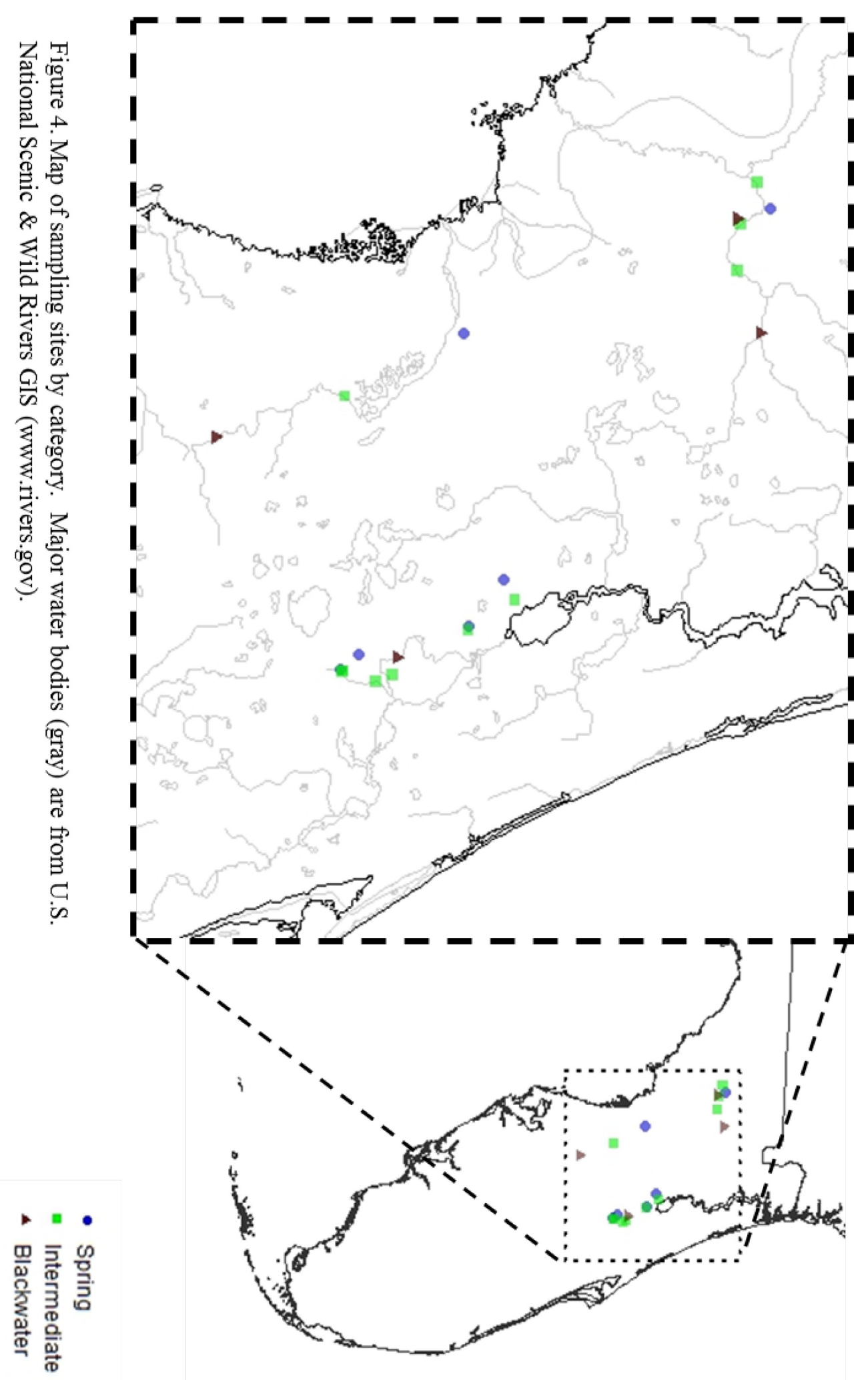




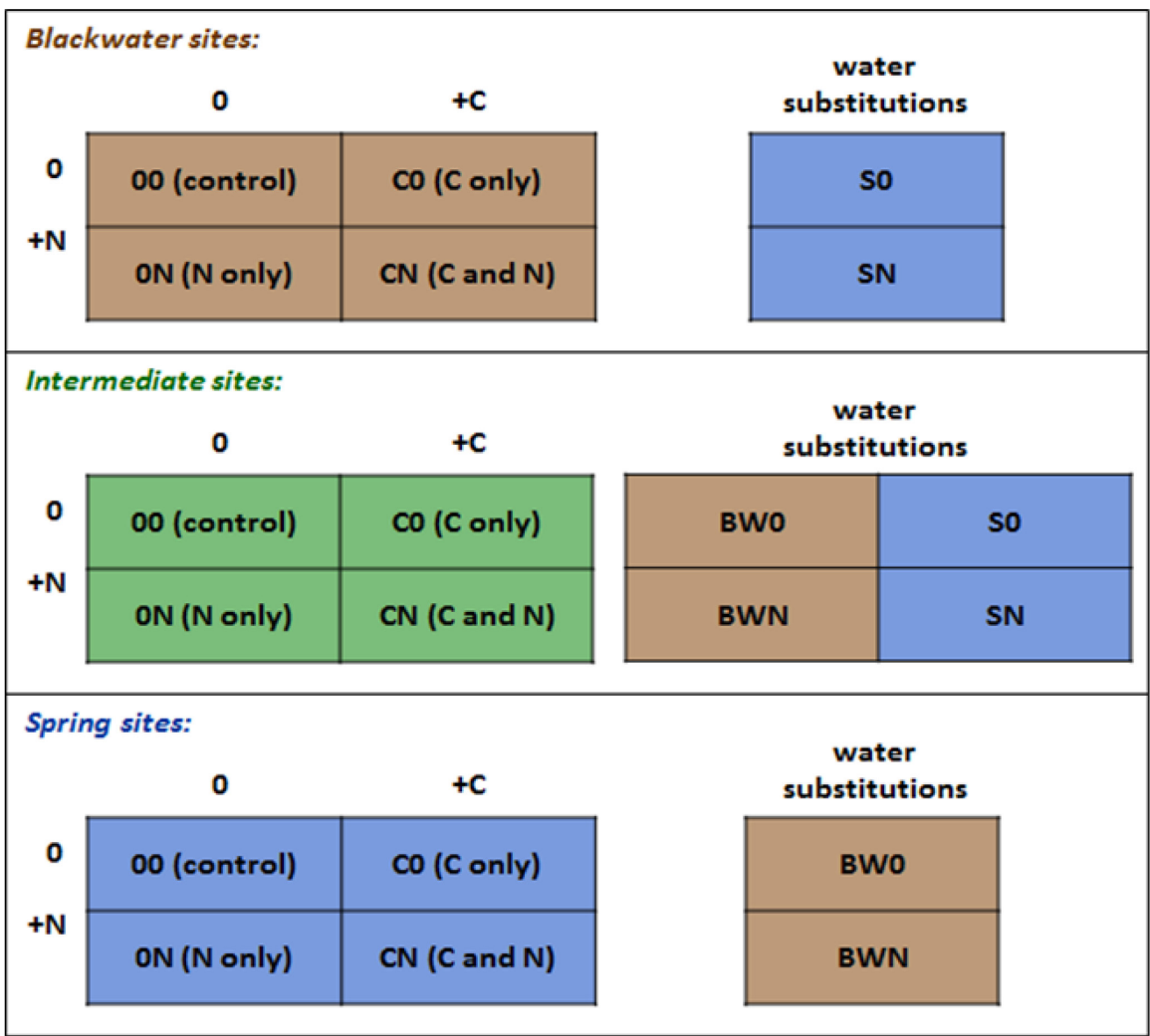

Figure 5. Treatments for sediment incubation experiments. Sediments were incubated with treatments consisting of source water factorially amended with carbon and nitrogen $(00, \mathrm{C} 0,0 \mathrm{~N}$, and $\mathrm{CN}$ treatments), as well as treatments made from alternate water types (water substitutions). Blackwater sediments were incubated with spring water ( $\mathrm{S} 0$ and $\mathrm{SN}$ treatments), spring sediments with blackwater (BW0 and BWN treatments), and intermediate sites were incubated with both spring and blackwater. 


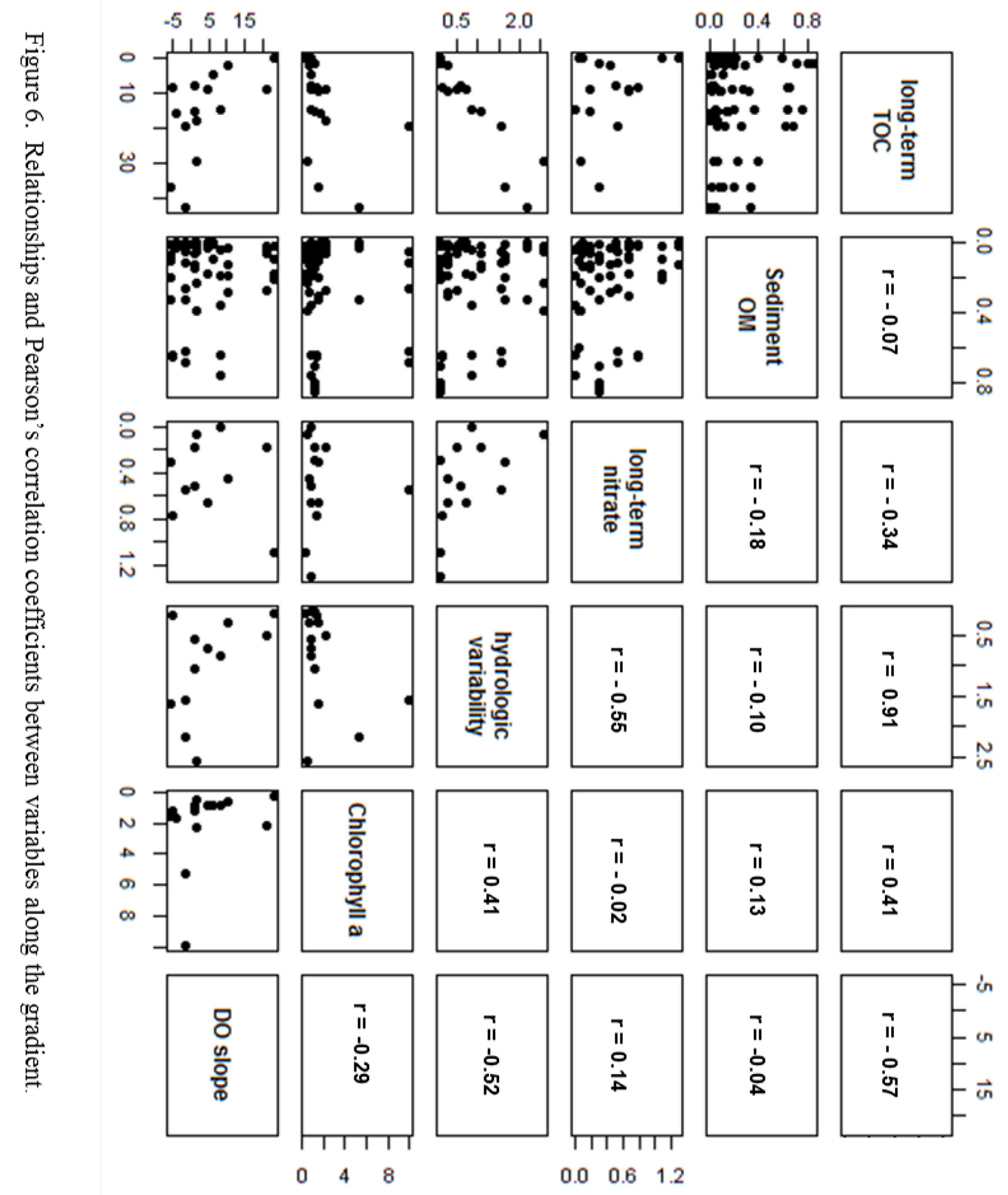



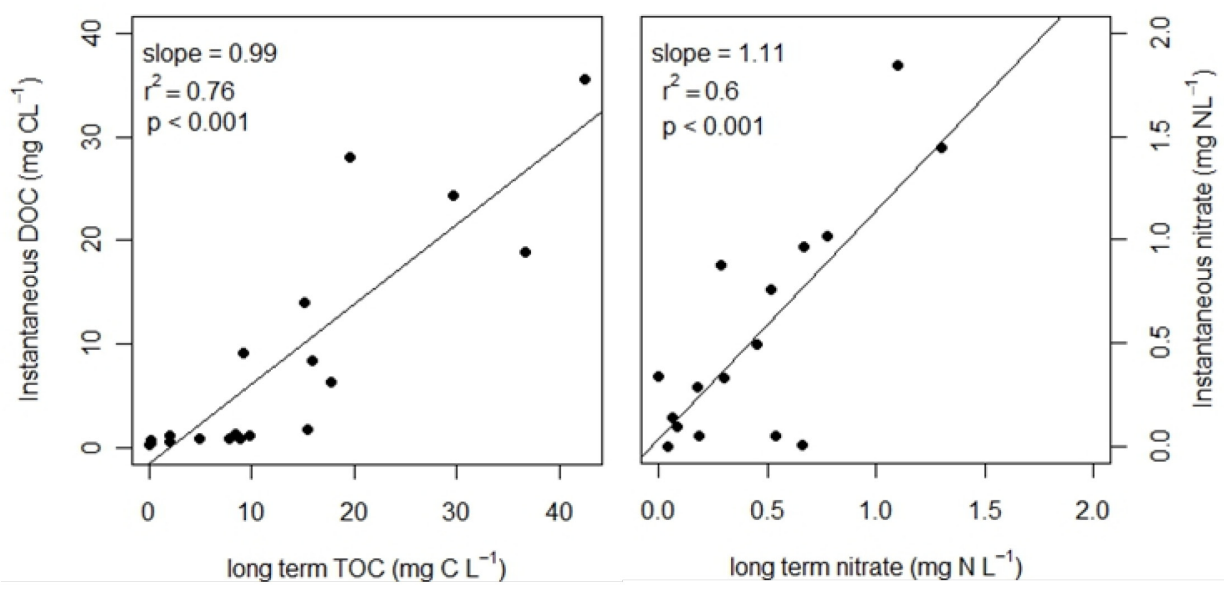

Figure 7. Correlation between instantaneous and long-term measurements of DOC/TOC and nitrate

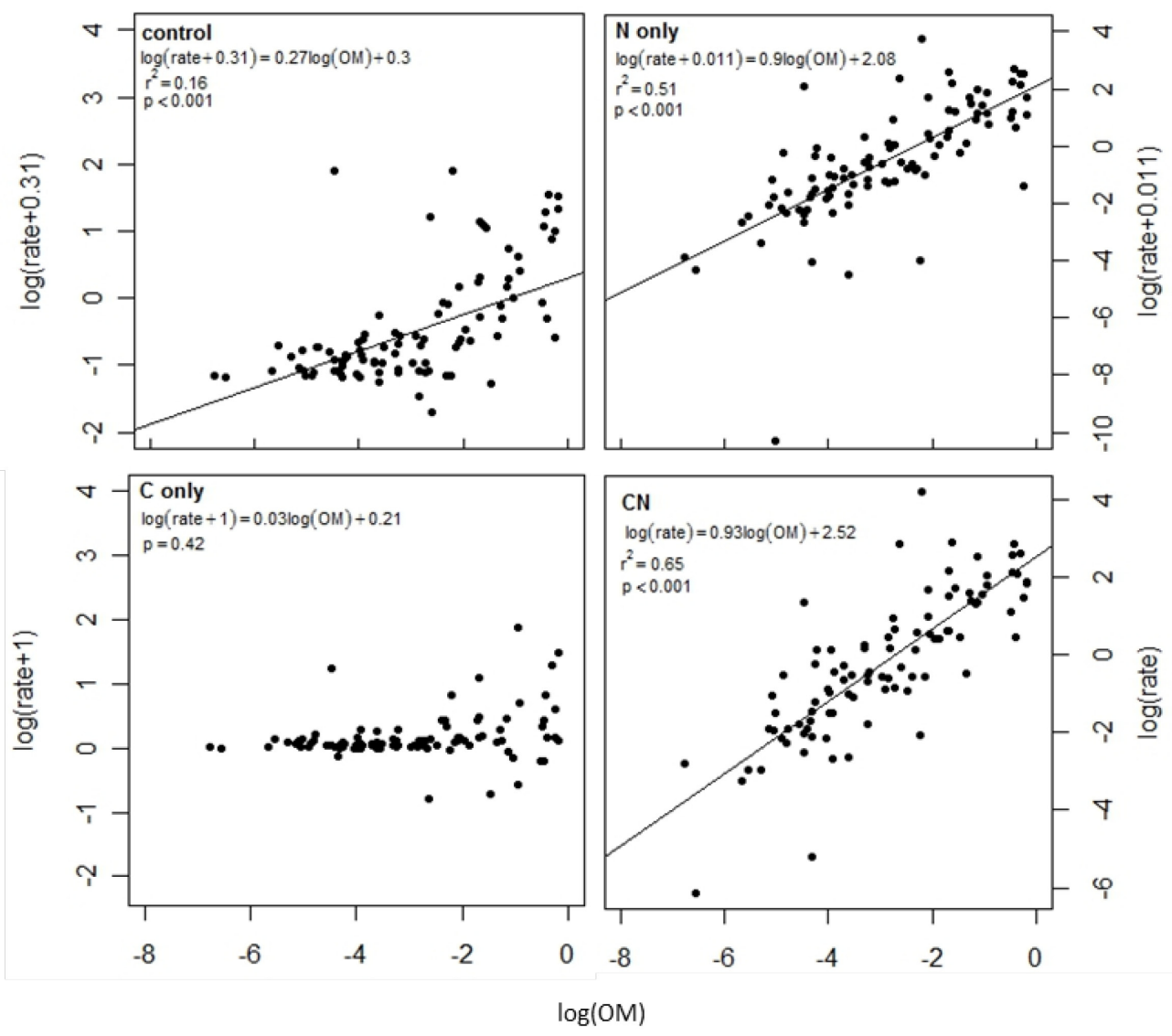

Figure 8. Effect of sediment organic matter (OM) content on denitrification rate for sediments under different nutrient amendments. Control treatment (upper left) is 0.45 micron filtered water from site of sediment collection, Conly treatment (upper right) is filtered site water amended with $1 \mathrm{mmol}$ dextrose, $N$ only (lower left) is filtered site water amended with $1 \mathrm{mmol}$ nitrate, and $C$ and $N$ (lower right) is filtered site water amended with $1 \mathrm{mmol}$ each of dextrose and nitrate. 


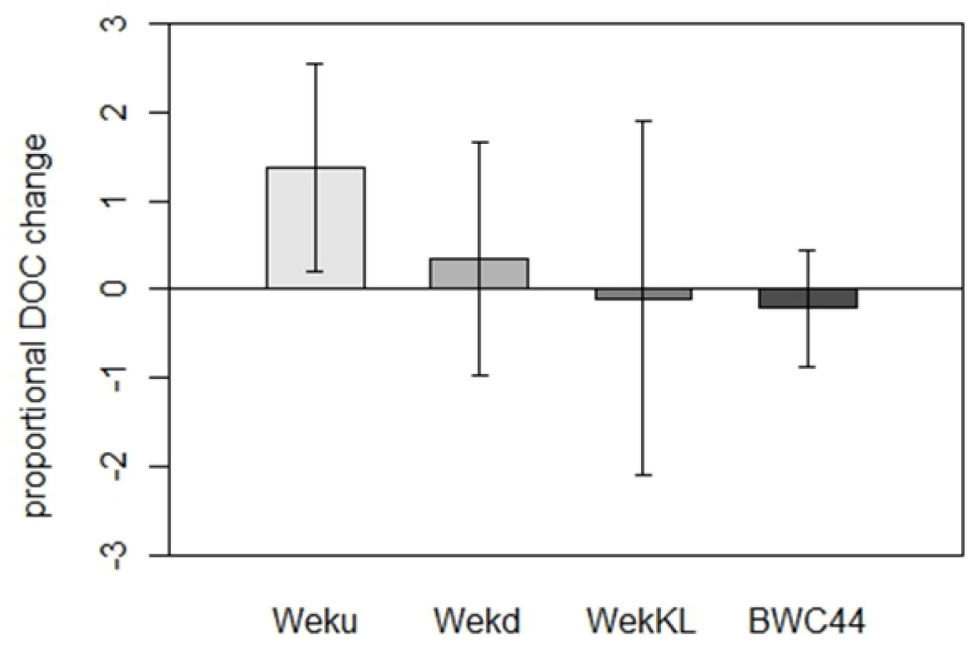

Figure 9. Proportional change in DOC during bioavailability incubation by site. Long-term TOC concentration increases from left to right. Differences in proportional change in DOC concentration over five day incubation were not significant $(p=0.32)$.

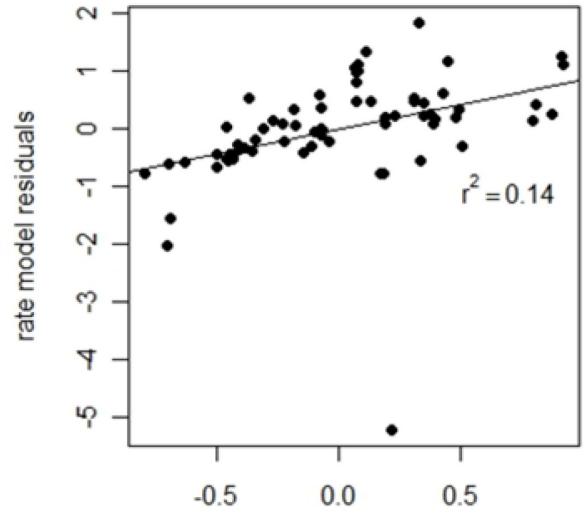

instantaneous nitrate model residuals

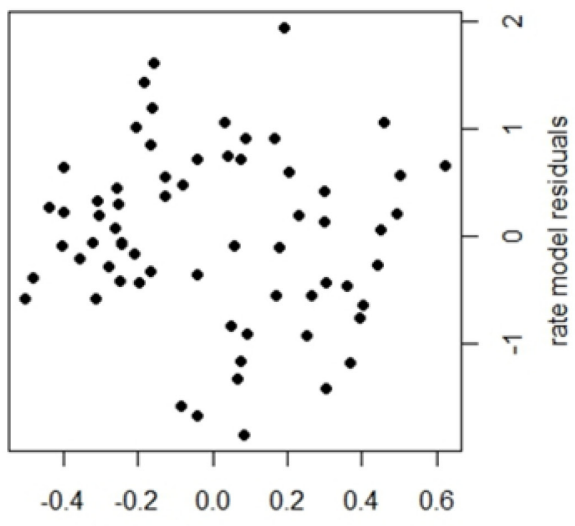

lona-term nitrate model residuals

Figure 10. Added variable plots for multiple regressions. Residuals of regression without nitrate parameter on ambient denitrification rates (left), and residuals of regression without nitrate parameter on potential denitrification rates (right), vs. residuals of regression of instantaneous nitrate concentration vs. other model parameters. 


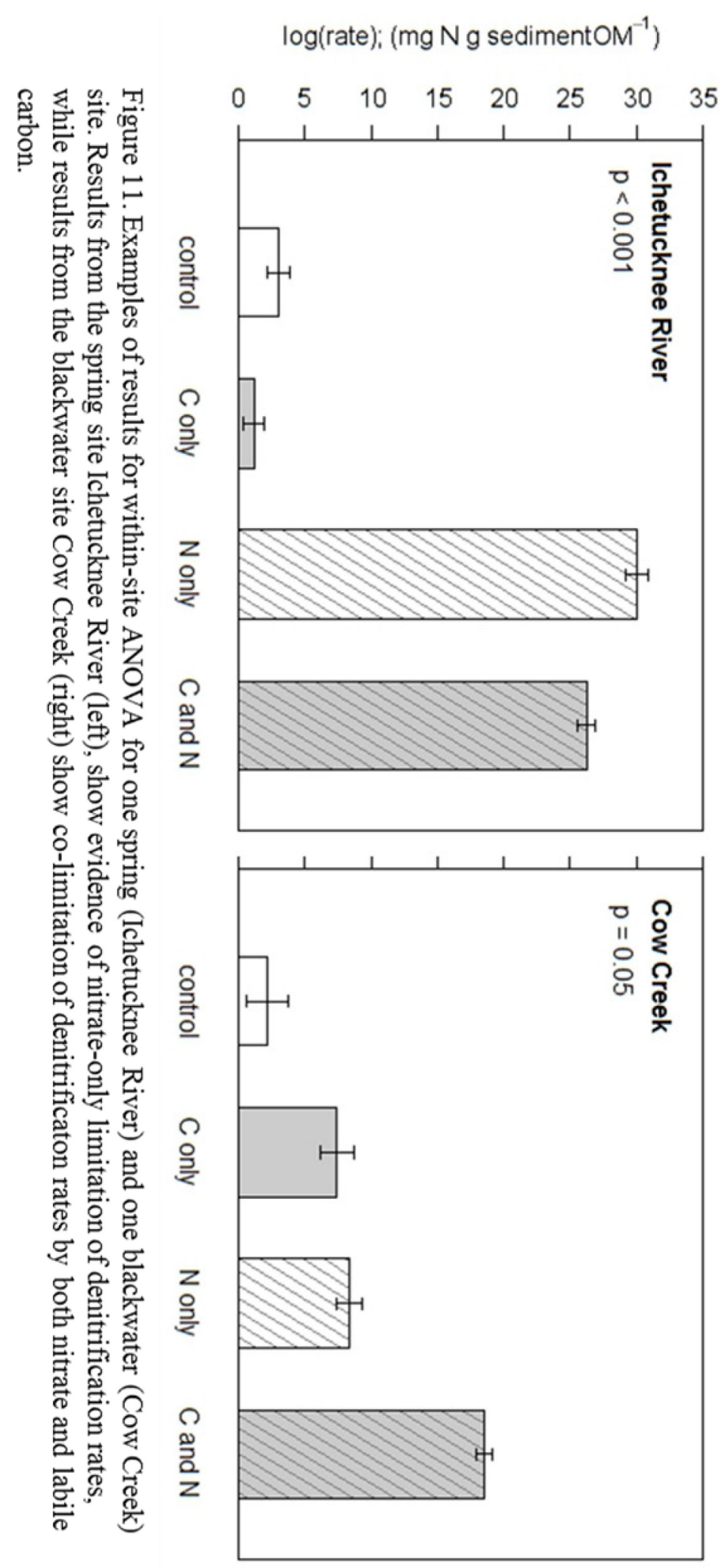




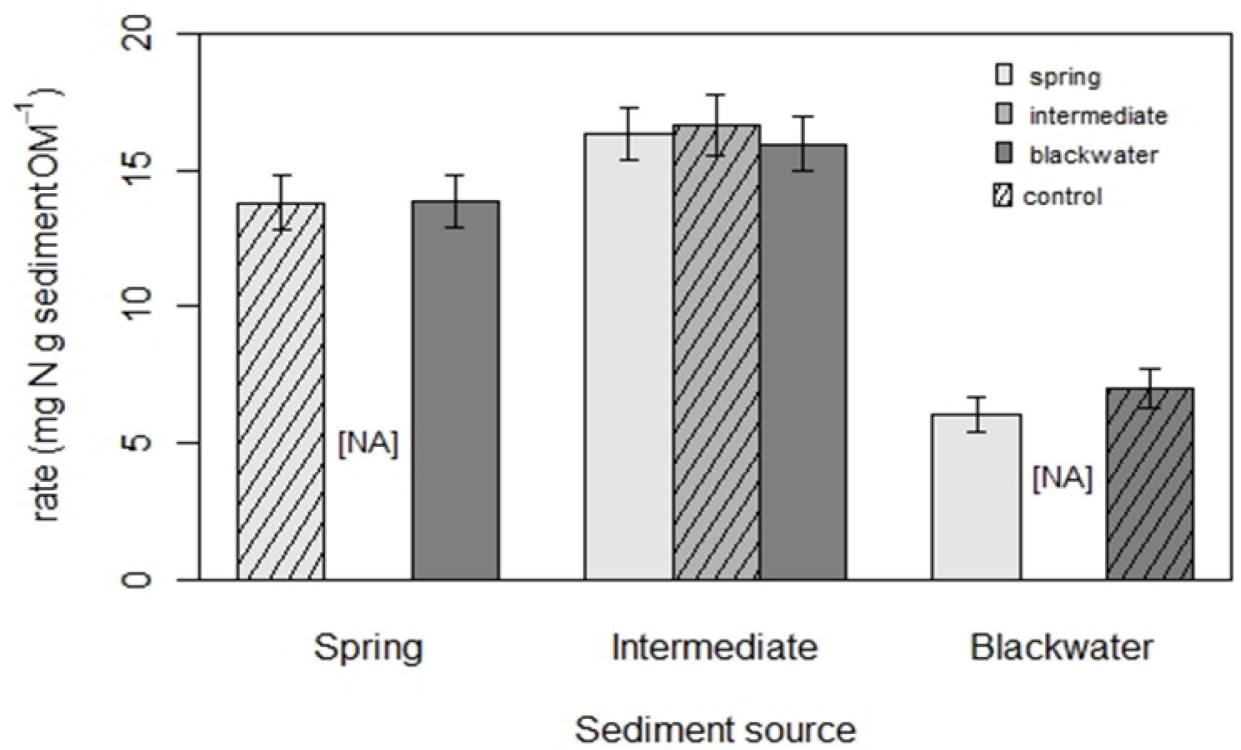

Figure 12. Denitrification rates for N-replete water substitution experiments by sediment source. Colors of bars represent water source; water from same source as sediment (controls) are shown by hashed bars. Water substitution did not produce significantly different denitrification rates within any of the sediment source groups (blackwater sediments, $p=0.65$; intermediate sediments, $p=0.60$; spring sediments, $p=0.53$ ).

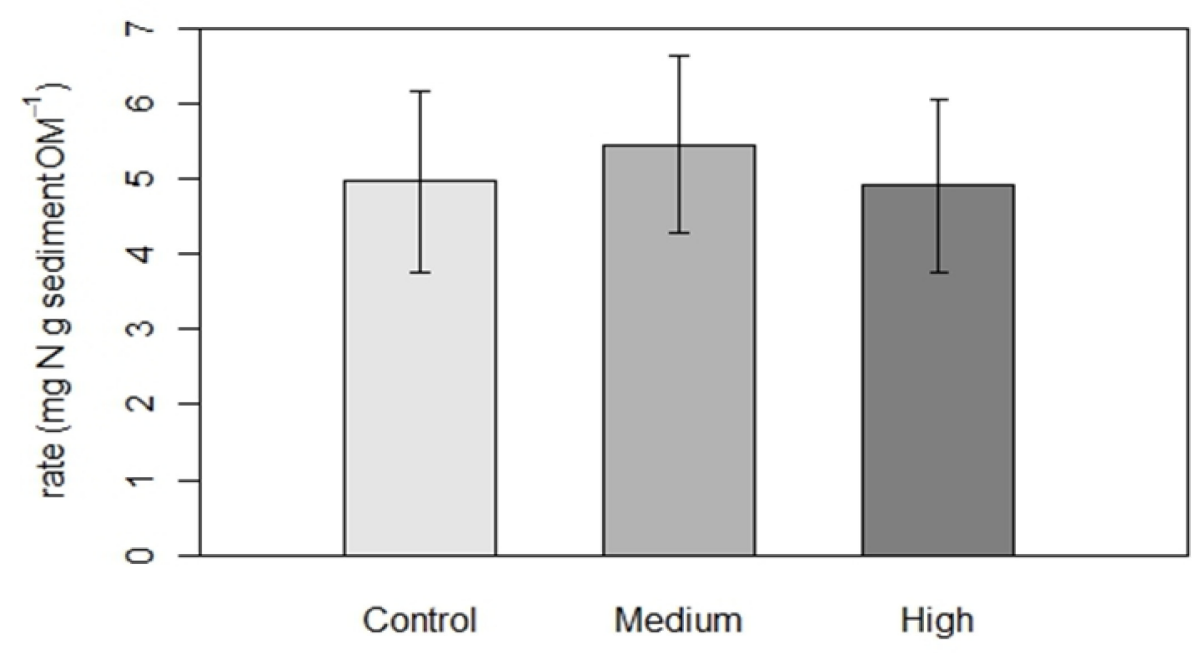

Humic acid dosing level

Figure 13. Denitrification rates vs. humic acid dosing level. Dosing of humic acid at concentrations of $50 \mathrm{mg} \mathrm{C} \mathrm{L}^{-1}$ (Medium) and $100 \mathrm{mg} \mathrm{C} \mathrm{L}^{-1}$ (High) neither significantly stimulated nor depressed denitrification rates as compared to the control (background) DOC levels $(p=0.84$ ). 


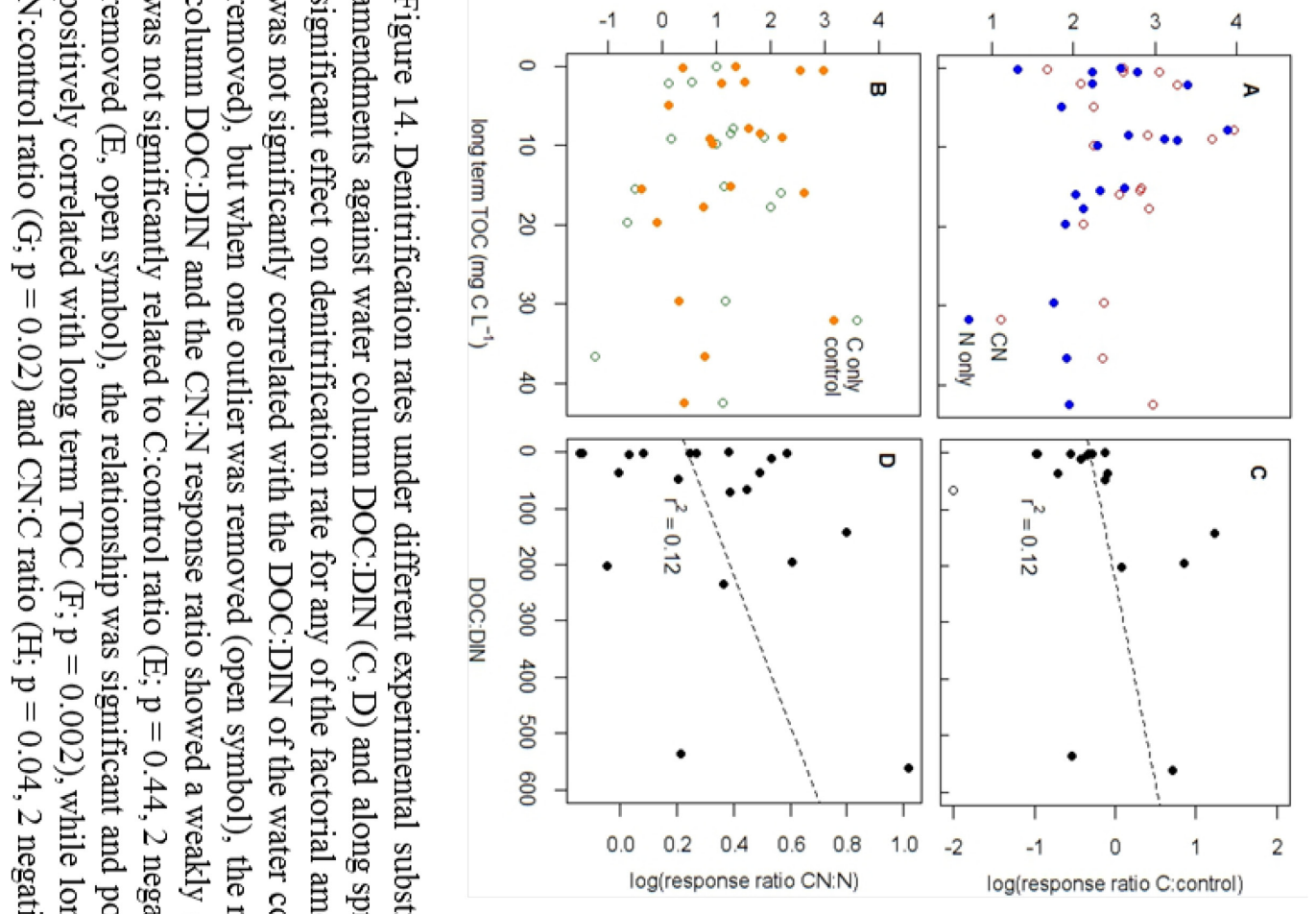

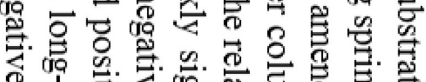

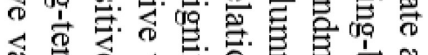

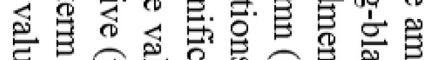

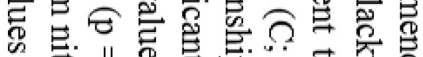
요욜

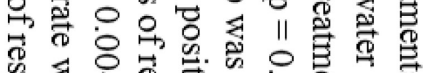

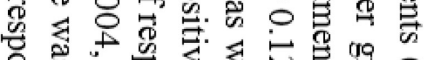

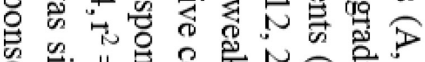

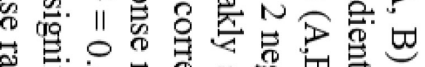

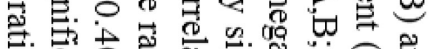

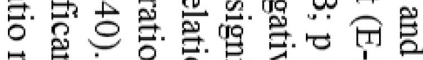

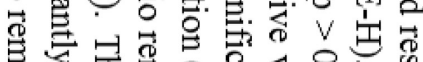

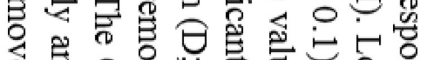

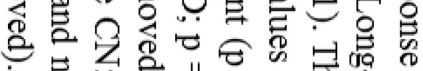

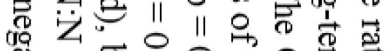

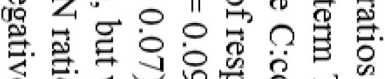

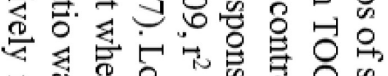

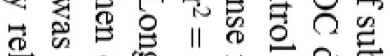

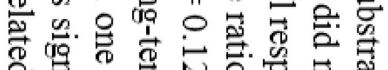

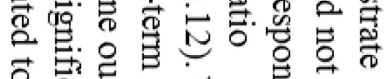

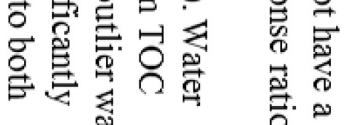

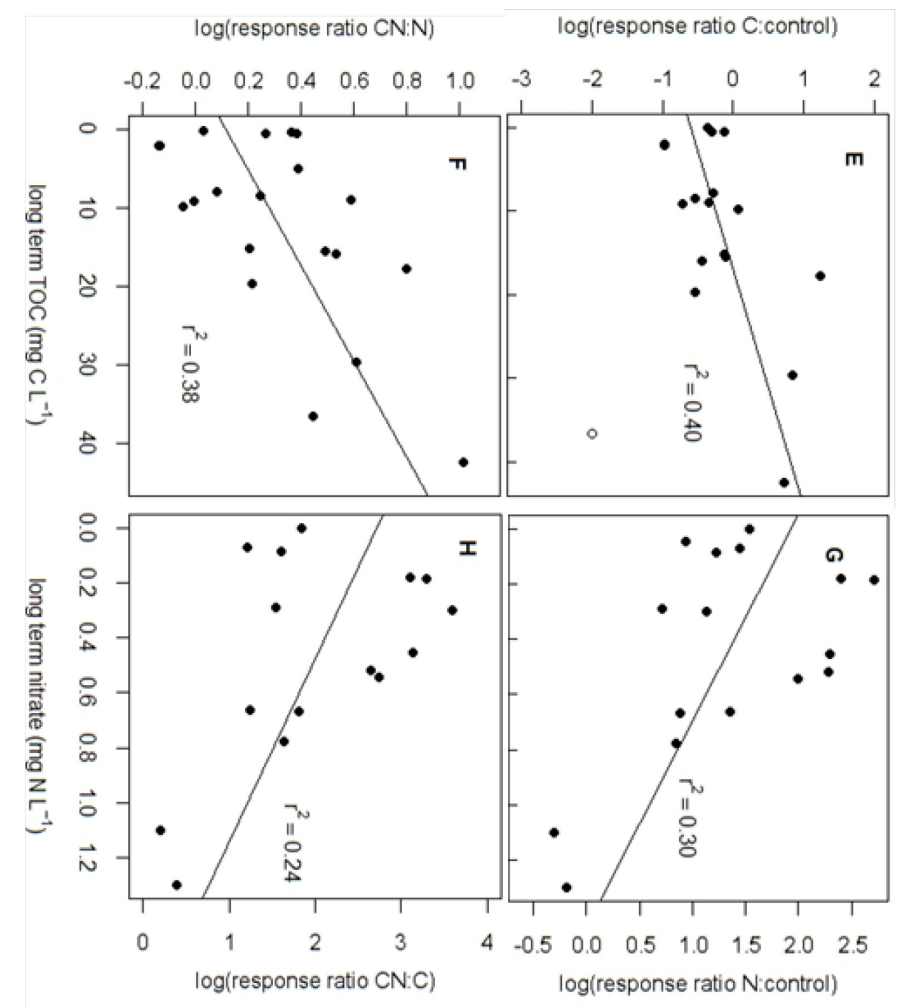

